A N N A LES

\begin{tabular}{l} 
UN I VERSITATIS M A R I A E C URIE-SKŁODOWSK A \\
LUBLIN - POLONIA \\
VOL. XIII, 2 \\
\hline
\end{tabular}

Akademia Muzyczna w Łodzi

BeAta StróżyńsKa

\title{
Józef Elsner jako twórca i propagator klasycznej symfonii ${ }^{1}$
}

Józef Elsner as a Composer and Propagator of Classical Symphony

Na przełomie wieków XVIII i XIX sytuacja kultury na ziemiach polskich była specyficzna. Długie lata panowania kultury sarmackiej, ze wszystkimi tego konsekwencjami dla sztuki, późniejsza działalność „oświeconych umysłów” za czasów Stanisława Augusta Poniatowskiego i wreszcie utrata państwowości spowodowały - paradoksalnie - nagłe ożywienie w dziedzinie kultury i próby nadrobienia straconych lat poprzez jak najszybsze odejście od wzorców barokowych i wczesnoklasycznych w kierunku już nie tylko klasycyzmu, lecz stopniowo także ku coraz wyraźniej zarysowującym się tendencjom romantycznym. O ile na terenach niemieckojęzycznych silnie zakorzeniona w wielu ośrodkach stylistyka barokowa stopniowo ustępowała, przekształcając się w styl galant, następnie przechodząc przez Empfindsamkeit, o tyle na ziemiach polskich nie zawsze można mówić w tym okresie o takich procesach. Niezwykle istotnym czynnikiem kształtującym nowy język muzyczny i bardziej wyraziste środki wyrazu było pojawienie się na terenach niemieckich tzw. „okresu burzy i naporu”, w którym zaczęto przełamywać sentymentalną słodycz, umiarkowanie i łagodność. Twór-

${ }^{1}$ Artykuł ten został oddany do druku znacznie wcześniej niż moja rozprawa habilitacyjna (zob. B. Stróżyńska, Symfonia w XVIII-wiecznej Polsce. Teoria, repertuar i cechy stylistyczne, Łódź 2015). Ostatecznie jednak wyżej wymieniona książka ukazała się jako pierwsza, stąd pewne partie niniejszego tekstu zostały w niej już opublikowane. 
czość klasyków wiedeńskich (i nie tylko wiedeńskich) stanowiła z jednej strony ukoronowanie nowoczesnych tendencji, zarysowanych około 1730 roku, z drugiej zaś strony otworzyła nową epokę w historii muzyki.

Stosunki społeczne panujące w XVII- i XVIII-wiecznej Polsce, brak monarchii absolutnej, a także na tyle silnego mieszczaństwa, aby mogło ono odegrać znaczącą rolę w kształtowaniu życia muzycznego, zaowocowały zacofaniem w dziedzinie nowoczesnego piśmiennictwa muzycznego. Efektem tego było znamienne dla kultury polskiej pierwszej połowy XIX wieku niezwykle dynamiczne przejście przez pozycje oświeceniowe ku tendencjom romantycznym. Ścieranie się poglądów konserwatywnych z postępowymi, jak to wtedy postrzegano, tworząc często sztuczne bariery między tym, co klasyczne, a tym, co romantyczne, powodowało niejednokrotnie pewne zagubienie i niekonsekwencje u osób wypowiadających się na ten temat. W sytuacji bowiem, w której „,romantyczne” było co prawda bardziej postępowe i nowoczesne, ale jednocześnie było postrzegane jako czynnik dezorganizujący uporządkowany świat klasyków, niełatwo było się odnaleźć. $Z$ dzisiejszej perspektywy ów ostry podział wydaje się nie do utrzymania, a działalność choćby tylko trzech klasyków wiedeńskich jest ewidentnie ewolucją, która poprzez twórczość Ludwiga van Beethovena prowadzi wprost ku dalszemu rozwojowi w twórczości romantyków; owe spory i okopywanie się na antagonistycznych pozycjach wydają się więc nieuzasadnione, jednakże z perspektywy ówczesnych muzyków były to sprawy o kardynalnym znaczeniu.

Józef Elsner żył w drugiej połowie XVIII i pierwszej połowie XIX wieku, co oznacza, że znalazł się w samym sercu tego sporu. Z jednej strony należał on do pokolenia, które zmieniało polską rzeczywistość muzyczną w imię idei oświeceniowych, z drugiej zaś jako pedagog, a także działacz społeczny, miał jednak świadomość, że ta ewolucja trwa, a filozofia, której służył, stopniowo jest wypierana przez prądy romantyczne; starał się więc zrozumieć zmieniającą się rzeczywistość. Alina Nowak-Romanowicz zarzuca mu eklektyzm, brak oryginalności i konsekwencji oraz specyficzną fluktuację, polegającą na zmienianiu poglądów z konserwatywnych na postępowe, a później z postępowych na konserwatywne ${ }^{2}$. Ten surowy osąd nie wydaje się do końca zasadny, gdyż Elsner całym sercem starał się służyć kulturze polskiej tak, jak potrafił najlepiej; przyszło mu jednak żyć i działać w czasach, kiedy musiał się zmierzyć z poważnymi i gwałtownymi przemianami.

Zupełnie inaczej wyglądała sytuacja pokolenia Chopina, które wchodziło w dorosłe życie w momencie krystalizowania się estetyki romantycznej i współ-

${ }^{2}$ A. Nowak-Romanowicz, Poglądy estetyczno-muzyczne Józefa Elsnera, [w:] T. Strumiłło, A. Nowak-Romanowicz, T. Kuryłowicz, Poglady na muzykę kompozytorów polskich doby przedchopinowskiej. Ogiński-Elsner-Kurpiński, Kraków 1960, s. 95. 
tworzyło nowe prądy, wnosząc swoją młodzieńczą energię i wiarę w to, że przyszedł czas na przemiany. Trzeba jednak pamiętać, iż Elsner urodził się w 1769 roku, a więc przeszło czterdzieści lat wcześniej niż jego genialny uczeń, a przyszło mu żyć jeszcze w pierwszych latach drugiej połowy XIX wieku, a więc już jako dorosły, dojrzały muzyk musiał się zmierzyć z nowymi prądami. Niewątpliwie toczył on wewnętrzną walkę, próbując zmieniać swoje poglądy na kwestie estetyczne. Wydaje się jednak, że mimo tego, iż większość życia przeżył już w XIX stuleciu, w głębi serca pozostał człowiekiem XVIII wieku.

\section{Poglądy Elsnera na muzykę instrumentalną}

Elsner niejednokrotnie wypowiadał się w swych pismach, artykułach i listach na temat muzyki, stąd nietrudno dzisiaj odtworzyć jego poglądy. Wśród wielu problemów, jakie poruszał, można odnaleźć także ślady rozważań na temat utworów instrumentalnych, ale ta tematyka wydawała się go interesować niejako na marginesie rozważań na temat muzyki wokalno-instrumentalnej. Mimo iż życie Elsnera przypadło na okres, w którym już można się spodziewać zrozumienia dla ogromnego, choć jakże odmiennego od muzyki wokalnej, potencjału dzieł pozbawionych warstwy słownej, to jednak przełamywanie owej bariery okazało się dla niego niezwykle trudne. Co prawda poglądy Elsnera ewoluowały w miarę upływu lat, ale jednak ślady myślenia XVIII-wiecznego i - co się z tym wiąże - deprecjonowania muzyki pozbawionej warstwy słownej były niezwykle wyraźne $e^{3}$.

Ostatecznie Elsner skłonił się ku temu, że muzyka instrumentalna posiada zdolność przemawiania bezpośrednio do serca i nawet może wywoływać nieokreślone uczucia. Nie zmieniło to jednak jego głębokiego przekonania, że prawdziwym sprawdzianem dla kompozytora jest skomponowanie opery, bo muzyka instrumentalna wywołuje krótkotrwałe ,zadziwienie”, a tylko muzyka wokalna wymaga „prawdziwego" talentu ${ }^{4}$ i użycia „wszystkiego, do czego tylko [...] muzyka jako piękny kunszt [...] jest zdatną"5. Słynne jest przekonanie Elsnera, że jego genialny uczeń powinien koniecznie zmierzyć się z operą, nie ograniczając

${ }^{3}$ W latach 1809-1813 ulegał on wpływom sensualistów. Muzyka miała oddziaływać na słuchacza poprzez wrażenia zmysłowe. Dopiero zmysły miały poruszać uczucia. Alina Nowak-Romanowicz przypuszcza, że zapewne było on pod wpływem poglądów Rameau, Baumgartena czy też J. Ch. G. Krausego. Według Krausego: „Wir empfinden [...] eine Lust der Sinnen, weil wir sie ohne das Gehör nicht haben würden. Diese Lust bleibet aber nicht bloss in den Ohren, sie theilet sich auch der Seele mit [...]”. Cyt. [za:] Nowak-Romanowicz, op. cit., s. 77.

${ }^{4}$ „Pamiętnik Warszawski” 1809, t. 9, s. 366. Cyt. [za:] ibid.

${ }^{5}$ J. Elsner, Rozprawa o melodii i śpiewie, 1830, s. 59. Cyt. [za:] ibid., s. 77-78. 
się do muzyki fortepianowej; ogólnie znany jest list Ludwiki do Fryderyka Chopina, w którym to liście napisała:

„p. Elsner nie chce Cię widzieć tylko koncercistą i kompozytorem fortepianowym i egzekutorem sławnym, bo to łatwiejsze i mniej znaczy, jak opery pisać [...] Twój geniusz nie ma osiąść na fortepianie i koncertach, Ty z oper masz się unieśmiertelnić"’.

Podobne stanowisko jak wielu teoretyków XVIII-wiecznych wyraził wcześniej twórca unikatowego jak na polskie warunki dzieła Sztuka muzyki dla młodzieży krajowej (1795-1796), ksiądz Wacław Sierakowski, według którego:

„Mechaniczna muzyka uszy tylko głaszcze, gdyż komu tajno, iż wody i wiatry grają; słowna zaś, jako rozumna, umysły nasyca, krępuje serca, wiąże afekta i jako zamierza, zniewala, kontentuje wszystkich, w wiadomościach objaśnia, w cnotach gruntuje, od złego odstręcza"7.

Autor ten uważał, że „muzyka pokojowa”, do której zaliczały się utwory instrumentalne, jest tworzona dla „dodania ochoty, wesołości, popisania się szukających z talentu chluby, zysku lub nagrody"

Obaj muzycy wpisywali się w ten sposób w królujący w XVIII-wiecznej Europie pogląd, iż „prawdziwa” muzyka, a więc ta poruszająca serce (a w polskiej rzeczywistości nade wszystko przekazująca narodowe treści), to dzieła wokalno-instrumentalne. Bardzo dobitnie wyraził to Johann Georg Sulzer:

„Na ostatnim miejscu postawimy użycie muzyki do koncertów publicznych, urządzanych jedynie gwoli zdobycia większej wprawy w grze. Tu zaliczyć trzeba koncerty, symfonie, sonaty, utwory solowe, które na ogół nie są hasłem niemiłym, lecz owszem, ożywiającym, bądź też służą grzecznej rozrywce, ale serca nie poruszają wcale""

\footnotetext{
${ }^{6}$ List Ludwiki Chopin do Fryderyka Chopina z dnia 27 listopada 1831 roku. Cyt. [za:] ibid., s. 78.

${ }^{7}$ W. Sierakowski, Sztuka muzyki dla młodzieży krajowej, Kraków 1795-1796, s. 7 i n. Cyt. [za:] L. Polony, Polski ksztalt sporu o istotę muzyki, Kraków 1991, s. 24.

${ }^{8}$ Sierakowski, op. cit., t. 1, s. 186. Cyt. [za:] Polony, op. cit., s. 24 n. Leszek Polony porównuje wypowiedź księdza Sierakowskiego z niemal mu współczesną publikacją Johanna Georga Sulzera z 1793 roku, w której można przeczytać: „Na ostatnim miejscu postawimy użycie muzyki do koncertów publicznych, urządzanych jedynie gwoli zdobycia większej wprawy w grze. Tu zaliczyć trzeba koncerty, symfonie, sonaty, utwory solowe, które na ogół nie są hasłem niemiłym, lecz owszem, ożywiającym, bądź też służą grzecznej rozrywce, ale serca nie poruszają wcale".

${ }^{9}$ Cyt. [za:] Polony, op. cit., s. 25.
} 
Także Charles Batteux napisał to, co myślało wielu filozofów tej epoki:

„muzyka sama z siebie jest bezduszna i niezrozumiała, kiedy nie przylega do słów, które muszą za nią przemawiać tak, aby wiedziano, co ona oznacza"10.

Batteaux uważał, że muzyka wokalna wiąże się z „belebte Töne”, instrumentalna zaś z „unbelebte Töne" ${ }^{11}$. Deprecjonował on na przykład sonatę, która wedhug niego jest „labiryntem tonów, które nie brzmią ani szczęśliwie, ani smutno, ani wzruszająco, ani poruszająco" 12 .

Elsner należał do zwolenników jakże typowego dla XVIII stulecia poglądu, iż śpiewność jest wartością nadrzędną i dobry instrumentalista to ten, który potrafi naśladować głos ludzki ${ }^{13}$ :

„grać dobrze na jakim instrumencie jest toż samo, co za pomocą tegoż instrumentu dobrze śpiewać. Żaden instrument nie może tak skutecznie działać co do uczucia naszego, jak głos ludzki. Ton jego jest tonem natury. Im więcej przeto ton instrumentu jakiego zbliżać się jest zdolny do głosu ludzkiego, tym więcej wpływa na uczucie"14.

Odwołanie do kategorii natury to najbardziej dobitne świadectwo tego, jak bliskie były Elsnerowi ideały XVIII wieku. To przecież jedno z naczelnych haseł stulecia.

Takie przekonania nadal stawiały muzykę instrumentalną na gorszej pozycji niż wokalna, jednakże można wnioskować, iż muzyka na instrumenty orkiestrowe, a więc m.in. symfonia, wydawała się Elsnerowi atrakcyjniejsza niż na przykład muzyka fortepianowa, która pobudza wyobraźnię, a nie uczucia, odchodząc w bardzo krótkim czasie w niepamięć. Wiadomo, że najwyżej cenił skrzypce, na których w przeciwieństwie do fortepianu muzyk może cieniować dźwięk. Według Elsnera skrzypce mogą wpływać na uczucia, ponieważ potrafią „zbliżyć się do głosu ludzkiego". Muzyka powinna zarówno ujmować, a więc działać na

${ }^{10} \mathrm{Ch}$. Batteux, Les beaux arts reduits à un même principe, Paryż 1746. Cyt. [za:] A. Mądry, Carl Philipp Emanuel Bach. Estetyka - stylistyka - dzieło, Poznań 2003, s. 26.

${ }^{11}$ C. Dahlhaus, Musikästhetik, Kolonia 1976, s. 34.

${ }^{12}$ Cyt. [za:] Mądry, op. cit., s. 26.

${ }^{13}$ Zob. B. Stróżyńska, Muzyka wokalna jako ideat i wzorzec dla twórców oraz odtwórców XVIII-wiecznych utworów instrumentalnych, [w:] Głos ludzki i instrumenty dęte. Wspólne aspekty techniczne i wykonawcze, Łódź 2007, s. 11-37.

${ }^{14}$ Recenzje koncertów warszawskich, pisane dla „Pamiętnika Warszawskiego” w latach 1809-1810. Cyt. [za:] Nowak-Romanowicz, op. cit., s. 78. 
serce, jak i zadziwiać, pobudzając wyobraźnię. Nawet najdoskonalsza gra instrumentalisty -

„Ze wszystkim, czym ono czaruje, czy to przez charakter właściwy instrumentu, czy to przez oryginalność kompozycji zastosowanej do uwydatnienia i podniesienia jego przymiotów - granie to, samo w sobie uważane, jest tylko środek na polu muzyki jako mowy uczuć"15.

Niewątpliwie problematyczne musiało być dla Elsnera uwielbienie współczesnych mu słuchaczy dla wirtuozów, gdyż w świetle bliskich mu poglądów teoretyków XVIII wieku biegłość techniczna, jako cel sam w sobie, musiała być oceniona negatywnie. Jednak także i w tym wypadku udało mu się wypracować złoty środek, ponieważ stwierdził, że wirtuozostwo też

„ma do pewnego stopnia i swoją stronę dodatnią, bo świadczy o wrażliwości na ogólną modę, o utrzymywaniu się w awangardzie postępu"16.

Ostatecznie symfonię postawił Elsner - obok opery - wśród dzieł, które mają szansę przetrwać i znaleźć uznanie także u kolejnych pokoleń ${ }^{17}$. Na marginesie można wspomnieć, że z kolei jego stosunek do koncertu solowego nie był do końca jednoznaczny, obok bowiem uznania dla tego gatunku wyraził też słowa krytyki w stosunku do koncertów w stylu brillant. Ciągłe pasaże traktował jak błyskotki, które oznaczają, iż kompozytor zanadto ulega aktualnej modzie. Wynikiem takiego postępowania miało być zapomnienie. Elsner pisał:

„Moda stanowi, moda niszczy”18.

To nie znaczy, że w utworze nie wolno było stosować jakichkolwiek „błyskotek", ale ich użycie miało być uzasadnione prawami logiczno-estetycznymi. Zdecydowanie występował przeciw samowolnemu upiększaniu przez wykonawców utworów innych kompozytorów swoimi ozdobnikami ${ }^{19}$.

Niezwykle istotne, że Elsner uważał utwór muzyczny, w tym utwór cykliczny (a więc i symfonię), za nierozerwalną całość. W XVIII wieku było normalną praktyką wykonywanie części symfonii w różnych miejscach koncertu. Na początku

\footnotetext{
${ }^{15}$ List Elsnera do Chopina z dnia 27 listopada 1831 roku. Cyt. [za:] ibid., s. 79.

${ }^{16}$ Bemerkungen über Musik in Warschau, „Allgemeine Musikalische Zeitung”, 3 czerwca 1811, nr 27, s. 449; cyt. [za:] ibid., s. 80.

${ }^{17}$ List Elsnera do Chopina z dnia 27 listopada 1831 roku. Cyt. [za:] ibid., s. 79.

${ }^{18}$ Cyt. [za:] ibid., s. 80.

${ }^{19}$ Por. np. „Pamiętnik Warszawski” 1810, t. 2, s. 281.
} 
wieku XIX zmieniła się filozofia myślenia o kompozytorze, jego roli i znaczeniu. Dostrzeżono w nim wybitną jednostkę kreującą dzieło sztuki. Dlatego wykonywanie tylko pojedynczych części kompozycji cyklicznych i zestawianie w ten sposób programów koncertowych zaczęło razić. Elsner wołał z oburzeniem:

„To nadużycie! Pojęcie całości w dziele znamieniem jest prawdziwego artysty" ${ }^{20}$.

Jego zdaniem to właśnie odróżnia rzemieślnika od człowieka sztuki. Obaj potrafią stworzyć części jakiejś konstrukcji, ale rzemieślnik robi to „bez zdolności zrobienia także wyobrażenia całości”21.

Około 1830 roku Elsner oficjalnie uznał prawo muzyki instrumentalnej do wyrażania uczuć, podobnie jak to ma miejsce w utworach wokalnych. Autor napisał:

„melodia [...] mieć powinna tyle wyrazu, iżby słuchający jej wyobrazić ją sobie mógł jako mowę człowieka przejętego jakim uczuciem, które przez tony wynurzyć zamierza" ${ }^{\prime 2}$.

To kolejne ewidentne nawiązanie do wypowiedzi niemieckich teoretyków na temat sonaty ${ }^{23}$. Można je porównać na przykład z poglądami Heinricha Christopha Kocha, przedstawiającego sonatę poprzez porównanie z wcześniej omówioną symfonią:

„melodia sonaty powinna się mieć tak do melodii symfonii, jak ma się melodia arii do melodii chóralnych, to jest - melodia sonaty (jako przedstawiająca uczucia jednej jedynej osoby) musi być najdoskonalej ukształtowana i jednocześnie przedstawiać najsubtelniejsze niuanse uczuciowe, z kolei melodia symfonii musi się wyróżniać nie tymi subtelnościami wyrazowymi, ale siłą i energią [dobitnością]. Krótko mówiąc, uczucia w sonacie i w symfonii muszą być inaczej przedstawiane i modyfikowane. [...] w sonacie części melodii nie przechodzą aż tak płynnie jedna w drugą jak w symfonii, ale częściej są rozdzielone przez jakieś odcinki i że nie są rozwijane tak często ani przez kontynuację cząstek tej albo innej melodycznej części, ani przez progresje, ale bardziej przez dookreślenie i objaśnienie uczucia" ${ }^{24}$.

${ }^{20}$ List do Chopina z dnia 27 listopada 1831 roku. Cyt. [za:] Nowak-Romanowicz, op. cit., s. 81 .

${ }^{21}$ Cyt. [za:] ibid., s. 81.

${ }^{22}$ Cyt. [za:] ibid., s. 83.

${ }^{23}$ Por. B. Stróżyńska, Drezdeńska sonata na instrumenty klawiszowe w drugiej połowie XVIII wieku, Łódź 2002.

${ }^{24}$, ,.... die Melodie der Sonate gegen die Melodie der Sinfonie eben so verhalten, wie die Melodie der Arie sich gegen der Melodie des Chors verhält, das ist, die Melodie der Sonate, weil sie 
Z punktu widzenia sztuki komponowania symfonii, a szczególnie formy sonatowej, wchodzącej w skład cyklu, niezwykle istotny jest pogląd Elsnera na sam akt tworzenia. Elsner widział w nim nade wszystko proces myślowy służący wyrażeniu określonej idei muzycznej. To jednak wcale nie oznacza, że myślenie miało być ważniejsze od natchnienia. Wręcz przeciwnie. W tej sprawie opowiadał się już on jednoznacznie za prymatem fantazji. W świetle jego rozważań w pierwszej fazie powstaje „zaród”, a więc plan dzieła, następnie pojawia się „egzekucja”, a więc wykonanie, wreszcie przychodzi czas na „wypracowanie”. Na początku kompozytor musi się skoncentrować na

„ustanowieniu zamiaru, czyli myśli i uczucia, jakie na umyśle słuchaczów sprawione być mają. [...] Kunsztownik nie tylko wszelkie natężenie umysłu zarodowi dzieła swego poświęcić winien, ale nadto nie wolno mu tykać się innych części pracy, dopóki ta główna z ukontentowaniem tworzącego dokonaną nie zostanie"25.

Z kolei „W wykonaniu owe istotne części ogółu ukształconymi zostają przez rozmaite obroty i rozczłonkowanie $\mathrm{w}$ wymiarze czasu, aby przeto czuciom wyrazić się mającym potrzebne nadać umiarkowanie”26. Na końcu „W wypracowaniu trudni się kunsztownik nawiasowymi pięknościami dzieła, słowem tym wszystkim, co by istotnie pilnikiem nazwać by można"27.

O ile czytając o rozczłonkowaniu, można od razu przypomnieć sobie słowa Kocha, o tyle w dalszej części wywodu Elsner nie pozostawiał wątpliwości, że to nie owo rozczłonkowanie, ale sam pomysł kompozytorski wydaje mu się centralnym punktem procesu tworzenia. To kardynalna różnica w stosunku na przykład

die Empfindungen einzelner Personen schildert, muß hochst ausgebildet seyn, und gleichsam die feinsten Nuancen der Empfindungen darstellen; da hingegen die Melodie der Sinfonie sich nicht durch solche Feinheiten des Ausdruckes; sondern durch Kraft und Nachdruck auszeichnen muß. Kurz, die Empfindungen müssen anders in der Sonate, und anders in der Sinfonie dargestellt und modificirt werden. [...] in der Sonate die melodischen Theile nicht so fortströmend zusammen hängen, wie in der Sinfonie, sondern öfterer durch förmliche Absätze getrennt, und weder so oft durch die Fortsetzung eines Gliedes dieses oder jenes melodischen Theils, noch durch Progressionen, sondern mehr durch erklärende, und die Empfindung auf das genaueste bestimmende Zusätze erweitert sind“" (przeł. B. S.). H. Ch. Koch, Versuch einer Anleitung zur Composition, cz. 1-3, Rudolstadt 1782, Lipsk 1787, 1793, Nachdruck Hildesheim 1969, cz. 3, s. 315-318.

${ }^{25}$ „Gazeta Koresp. Warsz. i Zagran.”, 23 marca 1813, nr 24. Cyt. [za:] Nowak-Romanowicz, op. cit., s. 81.

\footnotetext{
${ }^{26}$ Ibid., s. 82.

${ }^{27}$ Ibid.
} 
do zaleceń Francesco Galeazziego, który w Elementi teorico-pratici di musica ${ }^{28}$ twierdzi, iż stworzenie zbyt atrakcyjnego motywu (tematu) praktycznie uniemożliwia skomponowanie interesującego utworu. Autor ten jest zwolennikiem solidnego warsztatu, to znaczy pracy tematycznej, ponieważ to ona decyduje o umiejętnościach twórcy i to na niej należy się skoncentrować w procesie tworzenia. Wielkim mistrzem jest dla niego ten, kto potrafi doskonale rozplanować, doskonale stworzyć całą kompozycję, wykorzystując cały potencjał środków warsztatowych. Galeazzi posuwa się w tych radach jeszcze dalej - twierdzi, że właśnie stworzenie zbyt atrakcyjnego tematu spowoduje, iż napięcie słuchaczy będzie największe na samym początku, a później będzie już tylko spadać, co sprawi, że utwór wyda im się nieciekawy ${ }^{29}$.

Stanowisko Elsnera było z gruntu odmienne:

„każdy płód kunsztu najistotniejszą swą wartość czerpie w doskonałości swego zarodu; zaród zatem najwięcej od kompozytora wymaga genialności. Niechaj wykonanie i wypracowanie zmienia się z gustem czasu, jednakże szanowny zaród dzieła utrzymuje zawsze trwającą wartość! Prawda ta zasługuje szczególniej na uwagę tych, którzy zaślepieni modnymi pięknościami wypracowania, pojąć nie są w stanie, jak można dziełom dawniejszych kompozytorów tak wiele nadawać wartości’”30.

Według Elsnera „Pomysł w muzyce jest owocem talentu naturalnego, zaś opracowanie jest owocem wiedzy”31 , przy czym każda reguła, którą twórca zastosuje w opracowaniu powinna być ,przeniknięta siłą wyobrażenia, a także przez odpowiednie uczucie" ${ }^{32}$. Nie negując konieczności znajomości i odpowiedniego zastosowania reguł, w momencie pisania Przedmowy do Harmonii staje Elsner bliżej ideologii romantycznej, pisząc, iż kompozytor powinien być „przeniknięty tęsknotą sztuki i odczuciem oraz zachwyceniem”, jednakże wiele lat później, tworząc Rozprawę o melodii i śpiewie, napisze:

„Jenialni mistrzowie przelatują wprawdzie w napływie kunsztownych uniesień swoich pospolicie za granicę wszelkich reguł [...], ale wracają do

${ }^{28}$ F. Galeazzi, Elementi teorico-pratici di musica, t. 3, Turyn 1796. Suplement [w:] S. Schmalzriedt, Charakter und Drama. Zur historischen Analyse von Haydnschen und Beethovenschen Sonatensätzen, „Archiv für Musikwissenschaft” 42: 1985, z. 1, s. 50-66.

${ }^{29}$ Galeazzi, op. cit., cz. 4, rozdział 2, artykuł 3, 23 oraz 24.

${ }^{30}$ Cyt. [za:] Nowak-Romanowicz, op. cit., s. 82.

${ }^{31}$ Cyt. [za:] ibid., s. 82.

${ }^{32}$ Ibid., s. 83. 
nich później, tak iż dosięgając zupełnego wykształcenia, reguły te stosują do arcydzieł swoich i obrazy swoje ograniczają jakby ramami pewnymi”’33.

Wydaje się, że w przypisywaniu Elsnerowi zmiany poglądów z klasycznych na romantyczne należy zachować pewną ostrożność. Jego przekonania i pojęcia, jakimi się posługuje, są bowiem silnie osadzone w piśmiennictwie muzycznym XVIII wieku, choć oczywiście ulegają pewnym modyfikacjom i rozszerzeniu, choćby o wątki dotyczące związków z poezją. Na przykład jego stwierdzenia na temat traktowania muzyki (głównie wyrażającej się poprzez melodię) jako mowy uczuć i serca, a także postulat wzbudzania w słuchaczu uczuć przyjemnych i wzniosłych poprzez melodię są świadectwem tego, iż znał on XVIII-wieczne piśmiennictwo muzyczne. Odzwierciedlają one poglądy silnie zakorzenione właśnie w tym stuleciu, a tylko rozwijane twórczo w kolejnym wieku. Nawet same sformułowania są zaczerpnięte $\mathrm{z}$ niemieckojęzycznych pism XVIII wieku. W podobnym tonie jest utrzymana na przykład charakterystyka sonaty autorstwa Johanna Nikolausa Forkela w Musikalischer Almanach für Deutschland auf das Jahr 1784:

„Jak sobie wyobrażam sonatę, to wyobrażam sobie muzyczny sposób wyrażenia ekspresji człowieka, pogrążonego w uczuciach lub zachwycie, dążącego do tego, aby utrzymać swe uczucie na określonym poziomie (jeśli jest to $[\ldots]$ przyjemne uczucie) lub też, jeśli należy ono do grupy nieprzyjemnych, aby zmniejszyć jego siłę i zmienić je z nieprzyjemnego na przyjemniejsze. Oczywiście może zaistnieć też odwrotna sytuacja, to znaczy: przyjemne uczucie może być zmienione na nieprzyjemne. Ten ostatni przypadek jest jednakże niezwykle rzadko celem sztuki”34.

Wydaje się, że szczególnie hasła Empfindsamkeit, ale także innych kierunków i stylów tego stulecia, na przykład Sturm und Drang, są czasami błędnie utożsamiane z ideologią romantyczną, podczas kiedy ich źródłem są traktaty z XVIII, a nie XIX wieku. Nie ulega wątpliwości, iż niektóre z tych haseł, a szczególnie

${ }^{33}$ Ibid., s. 83.

34 „Wenn ich mir eine Sonate denke, so denke ich mir den musikalischen Ausdruck eines in Empfindung oder Begeisterung versetzten Menschen, der sich bestrebt, entweder seine Empfindung auf einem gewissen Punkte von Lebhaftigkeit zu erhalten, (wenn es [...] eine angenehme Empfindung ist;) oder sie, wenn sie in die Classe der unangenehmen gehört, von ihrer Höhe herunter zu stimmen, und aus einer unangenehmen in eine angenehmere zu verwandeln. Der Fall kann natürlich auch umgekehrt seyn, das heißt: die angenehme Empfindung kann in eine unangenehme verwandelt werden. Das letzte Verfahren ist aber höchst selten Zweck der Kunst“ (przeł. B. S). J. N. Forkel, Musikalischer Almanach für Deutschland auf das Jahr 1784, Lipsk 1783. 
uduchowiony język, jakim wówczas pisano o muzyce, wpłynęły tak silnie na kształtowanie się romantyzmu, że rzeczywiście można je odnaleźć także w pismach z kolejnego stulecia, ale nie wydaje się, aby w tej sytuacji zasadne było używanie ich jako argumentu, iż muzyk, który je wypowiadał w XIX wieku, wykazywał w ten sposób świadomość „dokonującego się romantycznego przełomu w sztuce" 35 .

Z wypowiedzi Elsnera wynika, że próbował on pokonać drogę od teorii afektów ku językowi romantyków, ale chyba najbardziej zasadne byłoby uznanie, iż jego epoką była epoka Beethovena, a więc trudny, ale i fascynujący czas ścierania się poglądów i krystalizowania nowych postaw. Elsner był jednym z tych, którzy bardziej zamykali starą, mijającą epokę, niż otwierali nową, postrzegając swoją misję w solidnym edukowaniu i umuzykalnianiu społeczeństwa; ale to jednak właśnie oni wychowali pokolenie romantyków, dając mu porządne podstawy warsztatowe i umiłowanie muzyki własnego narodu. Elsner stopniowo dojrzewał do przyjęcia nowej postawy wobec muzyki, która jest „mową uczucia i serca [...] zdatną dla wyrażenia różnych uczuć i namiętności" ${ }^{36}$, rozumiał wszakże te słowa przede wszystkim tak, jak je pojmowali ludzie oświecenia. Warto bowiem pamiętać, że już w XVIII wieku - mimo przywiązania do pewnych pojęć (np. natury) czy sformułowań (np. „muzyka jako mowa uczuć i serca”) - następowała dość radykalna ewolucja poglądów. Na przykład tak cenione naśladowanie natury wiązało się coraz bardziej z naśladowaniem natury ludzkiej, ludzkich uczuć i namiętności, choć oczywiście można znaleźć także liczne przykłady prostego malarstwa dźwiękowego, oddającego na przykład efekt burzy czy też śpiew ptaków. Stopniowo rodziło się przekonanie, że uczucia i namiętności nie musiały być nazywane, nie musiało się już więc pojawiać słowo. Wystarczyła komunikacja pomiędzy sercami twórców i odbiorców, którzy nierzadko sami byli także odtwórcami.

W pismach Elsnera można przeczytać wskazówki jakże dobrze znane każdemu badaczowi XVIII-wiecznych traktatów:

\footnotetext{
${ }^{35}$ Na przykład Małgorzata Kowalska twierdzi, iż: „,T. Strumiłło przytacza fragmenty Rozprawy o metryczności i rytmiczności, w której wypowiedzi Elsnera świadczą o jego świadomości w dziedzinie dokonującego się romantycznego przełomu w sztuce: «Dlatego najpierwszą jest rzeczą dla kompozytora, aby dobrze poznał rodzaj uczucia i jego stopień i aby się przejął samym duchem, jakim poeta był natchniony. [...] Aby wzbudzić w słuchaczu uczucia przyjemne i wzniosłe przez melodię - musi ona być natchnieniem wyrażenia namiętnego [...] Melodia staje się mową uczucia i serca»". M. Kowalska, Postać Józefa Elsnera w polskich podręcznikach, [w:] Józef Elsner (1769-1854). Życie - działalność - epoka, red. R. Pośpiech, [w serii:] Musica Claromontana - Studia 4, red. R. Pośpiech, Opole 2013, s. 373-374.

${ }^{36}$ Cyt. [za:] Nowak-Romanowicz, op. cit., s. 62.
} 
„wyraz radosnych uczuciów maluje się przez ruch żywy, raczej przez wysokie aniżeli niskie, raczej przez ucięte aniżeli przeciągane, raczej przez wzbijające się aniżeli stopniami, jeden po drugim następujące tony; rytm daje się bardziej pojąć aniżeli uczuć - tony wymagają umiarkowanego akcentowania etc. Ociężałe posuwanie się melodii i częste używanie dysonansów sprzeciwiają się temu rodzajowi uczucia i należy istotnie do wyrażeń smutnych etc. Wyraz szczytności wymaga średniowolnego ruchu, mocno uderzającego, oznaczonego rytmu $[\ldots]^{\prime 37}$;

„postępowanie diatoniczne ma coś lekkiego i przyjemnego, lecz chromatyczne coś bolesnego i czasem strasznego. [...] Mniejsze interwale spokojne, wielkie zaś niespokojne i żywe uczucia najlepiej wyobrażać mogą" 38 ;

„kwinta zmniejszona [...] w użyciu ma coś tkliwego i czułego [...] użycie zaś septymy zmniejszonej, w szczególności z góry na dół, w mowie muzycznej ma coś bolesnego"39.

Dokładnie takie - choć bardzo rozbudowane i uszczegółowione - wskazówki można odnaleźć chociażby w Kunst des reinen Satzes in der Musik Johanna Philippa Kirnbergera z lat siedemdziesiątych XVIII wieku ${ }^{40}$.

Znamienne, że choć ostatecznie Elsner pogodził się z tym, iż w jego czasach twórcy muzyki instrumentalnej wypracowali już takie środki wyrazu, że wreszcie po tak wielu wiekach mogła ona zostać uznana za równorzędną w stosunku do muzyki wokalnej:

„Muzyka [...] z jednego co i poezja pochodząca źródła, tj. uczucia ludzkiego, umie ona do niego przemawiać i, czyli to sama oddzielnie, czyli też z poezją, zawsze działa na nasze uczucia, podnosi wyobraźnię i językiem serca do serca przemawia"41,

to jednak do symfonii po 1805 roku wrócił już tylko jeden raz...

${ }^{37}$ „Gazeta Koresp. Warsz. i Zagran.” 30 marca 1813, dodatek do nr 26. Cyt. [za:] ibid., s. 73.

${ }^{38}$ Cyt. [za:] ibid.

${ }^{39}$ Cyt. [za:] ibid.

${ }^{40} \mathrm{~J}$. Ph. Kirnberger, Kunst des reinen Satzes in der Musik, cz. 1-2, Berlin - Königsberg 1771 i 1776-1779, reprint Hildesheim 1968.

${ }^{41}$ O muzyce w ogólności, „Astrea. Pamiętnik Narodowy” 1825, t. 1, s. 56-66. Cyt. [za:] Nowak-Romanowicz, op. cit., s. 84. 


\section{Twórczość symfoniczna}

Charakterystyczne dla drogi twórczej Elsnera jest to, że początkowo zdecydowanie wyżej cenił muzykę wokalną, co wiązało się w oczywisty sposób z ówczesnymi poglądami estetycznymi, ale to właśnie wtedy komponował chętnie utwory instrumentalne, natomiast później, kiedy już uznał, iż także ten typ muzyki może działać na uczucia, poświęcił się muzyce wokalno-instrumentalnej.

W młodości chętnie tworzył symfonie. Niemalże wszystkie zaginęły, ale ich wykaz jest dostępny, ponieważ spisał je sam kompozytor. Utwory na orkiestre bez śpiewu znalazły się w części piątej jego Sumariusza ${ }^{42}$. W dziale A. Symfonie twórca ujął następujące utwory:

„Wrocław

1. Nokturno in Es

2. Symfonia in Es

3. Symfonia in D

Powyższe trzy sztuki utworzyłem był we Wrocławiu nie umiejąc jeszcze dobrze głosów układać w partyturze. Pierwszą z nich napisałem dla orkiestry pana Lukaz. Drugą zaś po raz pierwszy wykonała orkiestra teatralna we dniu urodzin pani Weser, żony dyrektora teatru ${ }^{43}$.

We Lwowie

4. Międzyakta do tragedii Maria Stuart dla p. Bulli, dyrektora teatru.

5. Symfonia in $D$

6. Symfonia in $C$

7. Symfonia in Es

8. Symfonia in $D$ w Warszawie utworzona, której partytura pozostaje u Antoniego Andre ${ }^{44} \mathrm{w}$ Offenbachu, daną mu przez mnie w $1805 \mathrm{r}$.

9. Symfonia in $C$ sztychowana u p. Andre.

10. Symfonia in $B$ w partyturze; przeznaczona była do Konserwatorium, lecz nie wykonana.

11. Marsz z echem i andantem.

12. Wariacje z pieśni śpiewanej przez Elmanreidę w Szewcu, Es waren mir seelich Tage, przy tym echo i alla polacca, które się bardzo podobały.

${ }^{42}$ Zob.: J. Elsner, Sumariusz moich utworów muzycznych z objaśnieniami o czynnościach i działaniach moich jako artysty muzycznego, oprac. A. Nowak-Romanowicz, [w serii:] Źródła pamiętnikarsko-literackie do dziejów muzyki polskiej, red. T. Strumiłło, t. 4, Kraków 1957, s. 56-59.

${ }^{43}$ Według M. Schlesinger (Geschichte des Breslauer Theaters, 1898, t. 1) pani Weser była w tym czasie wdową i sama prowadziła teatr. Zob. Elsner, Sumariusz ..., s. 56.

${ }^{44}$ Jean Antoine André żył w latach 1775-1842. Był kompozytorem i wydawcą. Zob.: ibid. 
13. Koncert in $G$ na skrzypce (we Wrocławiu jeszcze bez ułożenia go w partyturze utworzony).

14. Koncert in $D$ na skrzypce, utworzony we Lwowie dla panny Simonowicz, u rodziców której schodziliśmy się co tydzień na kwartety z przyjacielem moim Bundesmannem, który z p. Kuniczem dawali lekcje pannie Simonowicz śpiewu i grania.

15. Dwa polonezy: jeden na orkiestrę i skrzypce solo z tematu opery Lodoiska, zaś drugi z marszu w operze Woziwoda. Obydwa sztychowane w Offenbachu u p. Andre.

16. Różne tańce, jako to walce - wiedeńskie, brueńskie, lwowskie, polonezy itd. Do odgrywania w czasie międzyaktów (w Warszawie)" ${ }^{m 5}$.

Jak widać, autor Sumariusza traktował określenie symfonia bardzo szeroko i właściwie wszystkie utwory na pełny skład orkiestry mieściły się w tym poję$\mathrm{ciu}^{46}$. Elsner był człowiekiem niezwykle pracowitym, a przy tym samokrytycznym; znamienna jest jego adnotacja o pierwszych symfoniach, które skomponował we Wrocławiu - nie były dziełami mistrzowskimi, gdyż nie umiał jeszcze wtedy rozpisywać głosów orkiestrowych. Co także znamienne, nie wydzielił utworów, które powstały w Warszawie. Takiego działu skądinąd w ogóle nie utworzył. Nie ulega wątpliwości, że było to jednak jego przeoczenie, ponieważ przy polonezach dopisał, iż służyły do odgrywania międzyaktów w Warszawie, a wcześniej - przy Symfonii D - jest dopisek, że powstała w Warszawie, Symfonie $B$ zaś przeznaczył do wykonania w Konserwatorium. Podobnie jednoznaczne są daty oddania nut do sztychowania. Utwory te mogły oczywiście zostać skomponowane dużo wcześniej, niż były oddane do owego sztychowania, ale inne, wskazane wyżej przesłanki świadczą o tym, że Elsner po prostu przez niedopatrzenie wydzielił tylko Wrocław i Lwów, zapominając o Warszawie.

Wzmiankę o symfoniach Elsnera można odnaleźć w pracy Dzieje symfonii w Polsce. Jej autor, Józef Reiss, wymienia Elsnera jako „niemal jedynego” przed-

${ }^{45}$ Cyt. [za:] ibid., s. 56-57.

${ }^{46}$ To ważny przyczynek do tematyki rozróżnień gatunkowych w muzyce instrumentalnej XVIII wieku (także i XIX). Oto kolejny dowód na to, że jeszcze po 1840 roku określenie symfonia nie dla wszystkich znaczyło to samo, a nie wolno zapominać, iż autorem Sumariusza był jeden z największych autorytetów w dziedzinie muzyki w ówczesnej Warszawie, profesor otoczony wielkim szacunkiem, wychowawca i mistrz jakże licznych muzyków, którzy kształtowali obraz polskiego (ale przecież nie tylko polskiego) życia muzycznego w XIX wieku. Elsner do grupy symfonii nie zaliczył (według oryginalnych określeń, jakie zostały przez autora użyte w tytułach poszczególnych działów) następujących kompozycji instrumentalnych: utworów na kilka instrumentów, utworów na fortepian z towarzyszeniem, utworów na fortepian bez towarzyszenia oraz utworów na instrumenty dęte. Zob.: ibid., s. 57-59. 
stawiciela polskiej symfoniki w tych trudnych czasach, pisząc zarazem o nim jako o Ślązaku, a nie Niemcu. Autor twierdzi, że:

„symfonie Elsnera wykonywano we Francji na koncertach w St. Cloud i w Tuillerach. Jako dyrygent orkiestry teatralnej we Lwowie, napisał Elsner na dochód ofiar wojny z r. 1790 symfonję D-dur; druga symfonja C-dur op. 11 wyszła nakładem Andrego w Offenbachu nad Menem, a symfonja B-dur op. 17 u Breitkopfa i Härtla w Lipsku. Symfonje te, jak wszystkie inne kompozycje Elsnera, mają dzisiaj tylko historyczną wartość" ${ }^{37}$.

Według wydanego przeszło sto lat później, niż został napisany Sumariusz, Słownika muzyków polskich Elsner skomponował: Symfonię Es-dur (Wrocław, około 1788-1789), Symfonię D-dur (Wrocław, około 1788-1789), Symfonię D-dur (Lwów, około 1795 roku), Symfonię C-dur (Lwów, około 1795 roku), Symfonię Es-dur (Lwów, około 1795 roku), Symfonię D-dur (Warszawa 1802, wykonanie - Warszawa, 12 listopada 1802 roku), Symfonię C-dur op. 11 (Warszawa 1804-5, wyd. Offenbach nad Menem 1805 J. Andre, wyk. 22 kwietnia 1805 Warszawa, rkp. partytury sporządzony przez Stefana Śledzińskiego w Bibl. COPIA Bydgoszcz), Symfonię $B$-dur op. 17 (Warszawa około 1818, Breitkopf und Härtel) ${ }^{48}$. Jak widać, została tu już przeprowadzona selekcja i mimo niewydzielania poszczególnych działów w grupie symfonii znalazły się tylko te utwory spośród podanych przez kompozytora, które noszą odpowiednią nazwę gatunkową. Dalej są wymienione koncerty etc.

W Stowniku muzyków polskich znalazły się już bliższe dane o poszczególnych utworach (niepełne, ale biorąc pod uwagę zapiski Elsnera, to i tak wnoszące cenne informacje o konkretnych lub też orientacyjnych datach i miejscach powstania kompozycji, a także o ich wydaniach). Kilka dalszych informacji przynosi artykuł poświęcony Elsnerowi w Encyklopedii Muzycznej PWM. Według Encyklopedii Elsner skomponował następujące symfonie ${ }^{49}$ :

Symfonia Es-dur, ok. 1788-89, prawykonanie we Wrocławiu, dedykowana pani Wäser, dyr. teatru wrocławskiego, Sumariusz - 56/2,

Symfonia D-dur, ok. 1788-89, Sumariusz - 56/3,

Symfonia D-dur, 1796, prawykonanie: Lwów, 2 grudnia 1796, Sumariusz 56/5,

Symfonia C-dur, 1796, prawykonanie: Lwów, 25 grudnia 1796, Sumariusz 56/6,

Symfonia Es-dur, 1797, prawykonanie: Lwów, 16 kwietnia 1797, Sumariusz 56/7,

${ }^{47}$ J. Reiss, Dzieje symfonji w Polsce, [w:] Muzyka polska, red. M. Gliński, Warszawa 1927, s. 132.

${ }^{48}$ Stownik muzyków polskich, red. J. Chomiński [i in.], t. 1, Kraków 1964, s. 128.

${ }^{49}$ Zob.: A. Nowak-Romanowicz, Elsner Józef, [w:] Encyklopedia Muzyczna PWM. Część biograficzna, red. E. Dziębowska, t. 3, Kraków 1987, s. 21. 
Symfonia D-dur, 1802, prawykonanie: Warszawa, 12 listopada 1802, Sumariusz 56/8,

Symfonia C-dur op. 11, 1804-5, prawykonanie: Warszawa, 22 kwietnia 1805, dedykowana W. Bogusławskiemu, wydana w formie głosów: Offenbach 1805, J. Andre, przechowywana w Universitätsbibliothek Berlin, Sumariusz 56/9,

Symfonia B-dur op. 17, ok. 1818, dedykowana hr. Rokickiemu, wydana: Lipsk 1818, Breitkopf \& Härtel.

Poza symfoniami Elsner tworzył również inne gatunki muzyki instrumentalnej przeznaczone na orkiestrę symfoniczną: Nocturno Es-dur, Walce wiedeńskie, Walce brneńskie, Marsz z echem i andantem, Karnevaltänze, Polonez na temat marsza z opery Woziwoda L. Cherubiniego, Polonez E-dur na temat uwertury z opery Lodoiska R. Kreutzera, Wariacje na temat arii z opery Żony przemienione czyli Szewc M. A. Portogalla, Polonez na temat piosenki Ou peut-on etre mieux..., 2 polonezy: F-dur i D-dur, Mazur, Marsz przedniej straży wojska polskiego, Marsz i 2 marsze dla Gwardii Narodowej. Kompozytor napisał też: Koncert skrzypcowy G-dur, Koncert fletowy oraz Koncert skrzypcowy D-dur. Na zespół dęty powstały marsze oraz inne utwory na różne okoliczności. Jednakże także i tu nie ma odniesienia do specyficznego podziału gatunkowego, jaki został zastosowany w Sumariuszu $u^{50}$.

Podsumowując - większość twórczości symfonicznej Elsnera przypada na lata 1788-1797. Działał on wtedy we Wrocławiu i we Lwowie. Kolejne trzy symfonie skomponował już w Warszawie. Warto podkreślić, iż niemalże wszystkie symfonie powstały do roku 1805 . W kolejnym półwieczu Elsner stworzył już tylko jeden tego typu utwór. Pierwsza z warszawskich symfonii została napisana w roku 1802. Wykonano ją 12 listopada 1802 roku. Kolejny utwór tego typu został skomponowany na przełomie lat 1804/1805. Ostatnia symfonia powstała około 1818 roku i w przeciwieństwie do poprzednich utworów nie wykonano jej w Warszawie.

O symfoniach wrocławskich trudno cokolwiek powiedzieć, jednakże ze względu na krytyczny stosunek do nich samego Elsnera można pokusić się o stwierdzenie, że były to jeszcze utwory niedojrzałe, niedoskonałe pod względem technicznym, warsztatowym, jakie bodaj każdy początkujący kompozytor ma w swym dorobku. Niewiele też wiadomo o symfoniach lwowskich. W tym czasie Elsner był organizatorem koncertów symfonicznych i zarazem wykonawcą, toteż ówczesny kontakt z najnowszym repertuarem symfonicznym mógł znacząco wpłynąć na jego dzieła.

\footnotetext{
${ }^{50}$ Zob.: ibid., s. 21.
} 


\section{Symfonia C-dur op. 11}

Styl symfoniki Elsnera w okresie warszawskim można dookreślić bliżej dzięki analizie zachowanej Symfonii C-dur op. 11. Powstała ona - jak było stwierdzone wcześniej - na przełomie lat 1804/1805, została zaś wykonana 22 kwietnia 1805 roku. W tym samym roku J. Andre w Offenbachu nad Menem wydał ją drukiem. Numer opusu został nadany symfonii przez samego Elsnera, który w ten sposób oznaczał osobno swoje utwory instrumentalne wydawane drukiem w zagranicznych oficynach wydawniczych, a osobno numerował swoje utwory religijne. Głosy tej symfonii znajdują się w berlińskiej Staatsbibliothek. Krzysztof Rottermund uważa, iż to jeden z najcenniejszych pierwodruków dzieł Elsnera ${ }^{51}$.

Data pierwszego wykonania Symfonii $C$-dur nie jest przypadkowa, gdyż był to utwór przeznaczony dla uświetnienia uroczystości imienin Wojciecha Bogusławskiego, który w tym czasie prowadził w Warszawie dwa teatry - polski i niemiecki. Według relacji reportera „Gazety Warszawskiej” uroczystość, która odbyła się w Pałacu Radziwiłłowskim, otwierała „Symfonia Wielka "52. Na karcie tytułowej znalazła się dedykacja dla Bogusławskiego:

Grande Symphonie Pour plusieurs instruments Dediee a Monsieur Adalbert de Boguslowski Entrepreneur et Directeur du theatre polonais et allemand de Varsovie par J. Elsner Oeuvre 11-me a Offenbach s. M. chez Jean Andre No 2179 - Prix 4 fl.".

Według Aliny Nowak-Romanowicz Symfonia C-dur powstała zimą 1804$-1805^{53}$, dedykacja bowiem zawiera informację, że Bogusławski jest dyrektorem m.in. teatru niemieckiego. Ponieważ funkcję tę objął w listopadzie 1804 roku, natomiast 22 kwietnia następnego roku utwór został wykonany, to nie ma pewności, czy była to zima, ale niewątpliwie musiał on być skomponowany między listopadem 1804 a kwietniem 1805 roku.

W Sumariuszu można przeczytać:

„W miesiącu kwietniu wybrałem się w podróż do Niemiec i Paryża nie w celu bynajmniej występowania tam w roli artysty, ale raczej dla osobi-

${ }^{51}$ Określony z racji swej wartości jako Rara, druk ten pochodzi z 1805 roku z oficyny Johanna Andre w Offenbach. K. Rottermund, Elsneriana ze zbiorów Staatsbibliothek zu Berlin, [w:] Józef Elsner (1769-1854). Życie - działalność - epoka ..., s. 189.

${ }^{52}$ „Gazeta Warszawska” nr 35 z dnia 30 kwietnia 1805 roku, Dodatek. Zob. A. Nowak-Romanowicz, Józef Elsner, [w serii:] Studia i materiały..., s. 98.

${ }^{53}$ Ibid. 
stego poznania znakomitszych artystów, obcowania z nimi, na koniec dla nauczenia się z wykonania ich dziel"s4.

Faktem jest jednak, że był jeszcze jeden cel tego wyjazdu. Otóż, Elsner chciał wydać swoje utwory drukiem, nawet na własny koszt, aby także inne narody poznały jego twórczość. W liście do wydawnictwa Breitkopf \& Härtel z 9 września 1815 roku, a więc dziesięć lat później, znajdą się słowa, które zdają się potwierdzać przekonanie kompozytora o łatwiejszym dostępie do miłośników muzyki w innych krajach w sytuacji, w której utwory zostaną wydane w znanym wydawnictwie: „bez wątpienia lepiej jest wędrować z Lipska niż z Warszawy, aby tu i ówdzie łatwiejszy zdobyć sukces" ${ }^{55}$. Wiadomo, że Elsner zabrał ze sobą zaginioną obecnie Symfonie $D$-dur oraz Symfonię C-dur op. 11. Pierwsza z nich nie została wydana drukiem. Na 56 stronie Sumariusza można odnaleźć tylko notatkę: „pozostaje u Antoniego Andre w Offenbachu dana mu przeze mnie w 1805 r.".

Współczesne wydanie Symfonii C-dur, przygotowane przez Alinę Nowak-Romanowicz, bazuje na zachowanym w Staatsbibliothek zu Berlin pierwodruku głosów. Odnalazł go Stefan Śledziński. Informację tę ogłosił w 1932 roku w pracy doktorskiej Dzieje symfonii warszawskiej w pierwszej połowie XIX wie$k u$. Mimo iż praca ta zaginęła, to zachował się jej skrót, a także rękopiśmienna partytura Śledzińskiego, która - mimo pewnych nieścisłości i korekt w stosunku do oryginału - także kilkadziesiąt lat po II wojnie światowej wciąż stanowiła materiał, na którym opierano się przy wykonaniach Symfonii C-dur Elsnera. Wydanie Aliny Nowak-Romanowicz z 1986 roku stanowi Zeszyt $X$ w serii Symfonie Polskie (pod redakcją Zygmunta M. Szweykowskiego).

W Symfonii C-dur Józefa Elsnera wyraźnie słychać elementy polskiej muzyki ludowej. Dzieło zostało skomponowane na klasyczną orkiestrę symfoniczną: kwintet smyczkowy, 2 flety, 2 oboje, 2 klarnety, 2 fagoty, 2 rogi, 2 trąbki i kotły. Niezwykle istotne zdaje się być dla kompozytora brzmienie klarnetów i fagotów. Pierwsza część poprzedzona jest wstępem w tempie adagio, w takcie 3/4. Powolne wstępy nie były powszechnie stosowane przez rodzimych kompozytorów, ale pojawiają się na przykład w Symfonii D (I) Pietrowskiego czy Symfonii D-dur na tematach uwertury do opery „Pasterz nad Wista” Wańskiego.

Symfonię Elsnera otwiera akord C-dur tutti w dynamice forte. Następnie milknie zespół instrumentów dętych, pauzują także kotły. Przez cztery takty grają tylko instrumenty smyczkowe. Początkowo prowadzą one unisono (w brzmie-

${ }^{54}$ Elsner, Sumariusz ..., s. 113.

${ }^{55}$ List z dnia 9 września 1815 roku, [w:] H. Opieński, Józef Elsner w świetle nieznanych listów, „Polski Rocznik Muzykologiczny” 1: 1935. Cyt. [za:] Nowak-Romanowicz, Józef Elsner, [w serii:] Studia i materiaty..., s. 98. 
niu $\mathrm{w}$ równoległych oktawach) melodię oscylującą w ruchu falującym między dźwiękami $c$ a $g$. Już od pierwszych taktów króluje w niej rytm punktowany, który stanie się rysem charakterystycznym części pierwszej. Zarówno dalszy rozwój wstępu i szybkiej części pierwszej wskazuje na niezwykle istotną rolę tej formuły rytmicznej. Mimo iż rytm punktowany w otwierającej cykl części powolnej nie jest w muzyce niczym nowym, stanowił bowiem chociażby w jakże popularnej uwerturze francuskiej rys charakterystyczny, wydaje się, że w tym wypadku kompozytor celowo splótł nim Adagio i Allegro, nadając mu poniekąd rolę spoiwa. Innym pomysłem zastosowanym przez Elsnera w Adagio jest pojawienie się krótkiego motywu, w którym brzmią tylko dwie nuty (w zapisie trzy), ale i tak jest on charakterystyczny ze względu na specyficzne rozwiązanie rytmiczne - ów motyw pojawia się na ostatniej szesnastce w grupie, połączonej łukiem z pierwszą ćwierćnutą w takcie i przechodzącej następnie na ćwierćnutę położoną o sekundę niżej. Naprzemienne pojawianie się tego motywu w różnych głosach, a więc w różnych instrumentach, różnych rejestrach (vl I, b, fl I, II + ob I, II), sprawia wrażenie troski o kolorystykę dzieła. Motyw ten jest prezentowany na tle repetowanych szesnastek w partiach skrzypiec II oraz altówek. Należy podkreślić, iż flety i oboje rozbudowują ten motyw zarówno w warstwie melodycznej, jak i harmonicznej. Jego dalszy rozwój prowadzi do prezentacji kantyleny granej solo przez klarnet I (później z fagotem I). W otwierającym symfonię Adagio solo klarnetu wprowadza melodię nawiązującą do niezwykle popularnych pieśni sentymentalnych, dumkowych. Od taktu 15 akompaniament przechodzi w bas Albertiego. Instrumenty dęte blaszane i kotły po krótkim epizodzie w taktach 12-13 powracają dopiero w takcie 26. Adagio zamyka mocne tutti. Ostatnim akordem jest dominanta podkreślona zatrzymaniem na fermacie.

Allegro, które pojawia się po wstępie, nie zaczyna się mocnym tutti. To częste zjawisko, że jeśli symfonię otwierał powolny wstęp, to kompozytor przenosił do niego tak charakterystyczne dla tego gatunku wyraziste, mocno zaznaczone motywy otwierające symfonię, grane najczęściej przez cały zespół, oparte na dźwiękach akordowych i prowadzone niejednokrotnie unisono. W tej sytuacji następująca po wstępie część szybka nie musiała już mieć fanfarowego początku. W symfonii Elsnera początkowy akord C-dur w części Allegro grają tylko skrzypce II, altówki i bas. Na drugiej ćwierćnucie fagot I i skrzypce I wprowadzają melodię w dynamice piano. Temat główny trwa 12 taktów (do taktu 52). Ma bardzo regularną budowę, wyraźnie wyodrębniają się kolejne czterotakty. Zamyka go tonika.

Po prezentacji tematu głównego pojawia się odcinek nawiązujący do wcześniej wspomnianych rytmów punktowanych, aczkolwiek także główny motyw tematu wykorzystuje tego typu rytm. Zgodnie z ówczesną konwencją podstawą budowy melodii są dźwięki akordowe, choć można też zaobserwować ruch se- 
kundowy. O ile temat był wprowadzony przez fagot I (solo) i skrzypce I na tle instrumentów smyczkowych, o tyle teraz ta grupa instrumentów milknie, natomiast rozbrzmiewa zgodny chór instrumentów dętych i kotłów. Po krótkiej odpowiedzi instrumentów smyczkowych pojawia się tutti.

Ekspozycja - ujęta w znaki powtórzenia - kończy się w takcie 127. Jej ostatni takt jest niemalże dosłownie powtórzony jako pierwszy takt części drugiej. W symfonii Elsnera można już pokusić się o użycie nazwy przetworzenie. Elsner korzysta ze zdobyczy klasycyzmu wiedeńskiego, opracowuje materiał ekspozycji, wykorzystując ukazane wcześniej motywy. To nie jest częste zjawisko na gruncie rodzimej symfonii. Polscy twórcy dość szybko przyswajali sobie zdobycze klasyków wiedeńskich, ale akurat przetworzenie należało do tych elementów, które kształtowały się z największym trudem. Rodzimym kompozytorom symfonii zdecydowanie bliższa była technika wariacyjna niż praca tematyczna, co zresztą odpowiada słowiańskiej praktyce i w drugiej połowie XIX wieku będzie wyraźnie zauważalne na gruncie muzyki rosyjskiej.

W takcie 155 następuje wyraźne zamknięcie pierwszego odcinka przetworzenia na dominancie wtrąconej do toniki szóstego stopnia. Ostatni akord jest wcześniej bardzo silnie umocniony, po czym wielokrotnie powtórzony. W takcie 156 pojawiają się motywy tematu głównego, ale nie w tonacji a-moll, tylko w A-dur. Są one przeprowadzone przez różne głosy - vl I, ob I, fl I i fg I. Repryza rozpoczyna się w takcie 194 po trwającej niemalże dwa takty pauzie generalnej. Wejście to jest bardzo dobrze przygotowane. Repryza odpowiada budowie ekspozycji (wbrew powszechnie powtarzanej formule, iż cechą charakterystyczną szkoły elsnerowskiej było rozpoczynanie repryzy wejściem tematu pobocznego; w rzeczywistości w ówczesnej Europie obie formuły istniały jednocześnie i pojawiały się w utworach tych samych twórców, co można obserwować także w twórczości Elsnera). Temat główny repryzy prezentują fagot I i skrzypce I przy akompaniamencie pozostałych instrumentów smyczkowych. Dopiero w takcie 218 pojawiają się oczywiste z punktu widzenia planu harmonicznego zmiany, gdyż w repryzie nie ma już procesu modulacyjnego, jaki był w ekspozycji.

Temat poboczny, który w ekspozycji pojawił się w takcie 78 (z przedtaktem) w tonacji G-dur, a więc w tonacji dominanty, teraz jest ukazany w takcie 231 (z przedtaktem) w tonacji zasadniczej. Także tu sposób instrumentacji jest analogiczny do ekspozycji. Temat prezentują najpierw skrzypce I z towarzyszeniem pozostałych instrumentów smyczkowych, później zaś, po ośmiu taktach, dołączają fl I i fg I, i to one przez cztery takty grają wraz ze skrzypcami I melodię tematu. Temat poboczny tylko „dobarwiają" pojedynczymi nutami inne instrumenty dęte. Zarówno w ekspozycji, jak i w repryzie temat poboczny jest wyraźnie poprzedzony kadencją, a dodatkowo jeszcze pojawia się określenie dolce, tak charakterystyczne dla tego typu tematów dru- 
giej połowy XVIII wieku. Równie typowy jest przebieg melodyczny tematu - oparty przede wszystkim na dźwiękach akordowych (główny motyw) i pochodach dźwięków gamowłaściwych. W dalszym przebiegu repryzy powracają rytmy punktowane, które - o czym już była mowa - stanowią wyraźne spoiwo tej części. W końcowej fazie repryzy instrumenty smyczkowe są traktowane często jako jeden blok - zdarza się, że prowadzą melodię unisono (w równoległych oktawach), jak np. w taktach 255-267, przy czym często ćwierćnuty są podzielone na repetowane triole. Zdarzają się niewielkie odcinki przebiegów chromatycznych, ale wydaje się, że wynikają one raczej z logiki przebiegu harmonicznego, a nie są świadomym aktem budowania melodii o charakterze chromatycznym dla uzyskania szczególnego wyrazu emocjonalnego.

Instrumenty dęte są przez Elsnera prowadzone całymi blokami, co wyraźnie odzwierciedla ich rolę jako czynnika tworzącego specyficzną barwę orkiestry klasycznej. Kompozytor ma wyraźne upodobanie do fanfarowych, bardzo mocno podkreślonych zwrotów kadencyjnych, w których uczestniczą wszystkie instrumenty dęte. Zgodnie z duchem mijającej epoki trudno w nich dostrzec rozwiązania harmoniczne odbiegające od typowych formuł tego okresu. Powracają za to wielokrotnie powtórzenia tych samych akordów w fanfarowym rytmie: ćwierćnuta - ósemka z kropką - szesnastka - dwie ćwierćnuty i zamknięcie na pierwszej ćwierćnucie następnego taktu.

Druga część symfonii, Andante, jest utrzymana w tonacji subdominanty (F-dur) w takcie 6/8. Zaczyna się (tym razem z przedtaktem) bezpretensjonalną melodią, nawiązującą w swej prostocie do lekkości stylu wiedeńskich mistrzów epoki klasycyzmu. Wyraźne preferowanie przez Elsnera brzmienia fagotu także w tej części przejawia się w powierzeniu temu instrumentowi (fg I) melodii (obok skrzypiec i altówek). Część ta zaczyna się w dynamice piano, pojawia się określenie dolce. Motywy początkowe w tonacji zasadniczej powracają w takcie 71 (z przedtaktem), a wcześniej w takcie 23 (także z przedtaktem). W Andante uwagę zwraca rozdrobniona, skomplikowana rytmika - obok bardzo licznych szesnastek pojawiają się trzydziestodwójki, punktacja (czasami w postaci rytmów lombardzkich), triole etc. Elsner nie należał do twórców, którzy chętnie stosowali pochody chromatyczne, jednakże w tej części można odnaleźć pewne próby przełamania diatoniki.

Pojawiają się ostre zestawienia dynamiczne w kolejnych szesnastkach, co oznacza zmianę dynamiki z forte na piano w partiach instrumentów smyczkowych i fagotów co szesnastka (np. w takcie 42). Oznaczenia dynamiczne wydają się dla kompozytora niezwykle istotne. Na przykład we wspomnianym powyżej takcie 42 w partiach fletów, obojów, klarnetów i rogów przy każdej szesnastce jest określenie forte. Nie ma żadnych zmian dynamicznych. Jedynym uzasadnieniem takiej troski jest oddzielanie kolejnych nut pauzami szesnastkowymi. 
W tej części warto zwrócić uwagę na przechodzenie motywów między poszczególnymi instrumentami, a więc wykorzystywanie kolorystyki (np. w taktach 31-50). Elsner operuje barwami, łącząc instrumenty w grupy jednolite brzmieniowo. Obok oczywistego połączenia smyczków pojawiają się wspomniane powyżej zestawienia fagotu z instrumentami smyczkowymi czy też łączenia w jedną grupę instrumentów dętych drewnianych (np. fl I, ob I, fg I). Klarnet I bywa traktowany jako instrument melodyczny, ale także jako podpora, towarzysząc na przykład obojowi I (np. od taktu 10 z przedtaktem). Odrębnie traktowane są rogi, które w orkiestrze klasycznej mają jasno wyznaczoną rolę. Podobnie, aczkolwiek zupełnie marginalnie, potraktowane są clarini. W części tej pojawia się divisi, a także artykulacja staccato.

Pierwszy ośmiotakt Adagia jest ujęty w znaki powtórzenia. Cząstka, która się zaczyna w takcie 9, nie opiera się na nowym materiale motywicznym. Konsekwentnie przetwarzane są motywy z pierwszego ośmiotaktu. Wspominane wyżej zróżnicowanie dynamiczne drugiej części symfonii zauważalne jest już po dwóch taktach, kiedy Elsner zaznacza forte przedtakt (ósemkę), by wycofać dynamikę do piana na pierwszą, najmocniejszą część taktu. Tym mocniej brzmi ćwierćnuta, która przypada na drugą ósemkę w takcie, oznaczona jako forte. Kolejna mocna część taktu znów jest jednak w piano. To przesuwanie akcentów było charakterystyczne dla muzyki polskiej i Elsner zapewne chciał w ten sposób podkreślić rodowód swej symfonii. Zdwojenia tercjowe pojawiają się, ale nie jest to już taka maniera, jak u większości polskich twórców XVIII-wiecznej symfonii.

Skomplikowana, rozdrobniona rytmika drugiej części nie wiąże się już z dużą liczbą ozdobników, jak to było w stylu galant, w utworach twórców tzw. fryderycjańskiego rokoka. Ozdobniki są zjawiskiem wyjątkowym (np. przednutka krótka w partii skrzypiec I w takcie 95). Pochodom diatonicznym odpowiadają postępy chromatyczne (np. w taktach 102-103); i w tym wypadku był to z pewnością efekt zamierzony przez twórcę. Warto jeszcze przyjrzeć się końcowej kadencji w tonacji F-dur: tonika - dominanta nonowa bez prymy wtrącona do subdominanty II stopnia - dominanta nonowa bez prymy - tonika - dominanta nonowa bez prymy - tonika - dominanta nonowa bez prymy wtrącona do subdominanty II stopnia - dominanta nonowa bez prymy - tonika - dominanta nonowa bez prymy - tonika, która jest powtarzana przez dwa kolejne takty. Cała ta kadencja rozgrywa się na stojącym w basie dźwięku $F$. To charakterystyczne dla Elsnera. Eksploatuje on wielokrotnie te same połączenia, uporczywie wracając do toniki. To jedna z cech, które nie pozwalają zaliczyć go do grona kompozytorów romantycznych. Elsner trwa przy klasycznych konwencjach. Spełnia w ten sposób oczekiwania szerokich mas odbiorców muzyki swych czasów, jednocześnie nie czyni kroku naprzód - nie wymaga od tychże odbiorców wysiłku podążenia za nim, za jego koncepcją czy też wizją, jak by to chętniej określili romantycy. Pozostaje w służbie społeczeństwa, co jest typową postawą w epoce, w której 
się urodził i wychował. Chce swoją muzyką edukować i sprawiać przyjemność; nie przeprowadza słuchaczy przez meandry własnej wyobraźni, nie podąża nieprzetartymi ścieżkami. Jest autorytetem jako profesor, jako działacz, ale jednocześnie chce być rozumiany i akceptowany jako kompozytor. Nowak-Romanowicz pisała:

„Jeszcze jeden postulat spełniła muzyka Elsnera - potrafiła wzruszać, a nawet doprowadzać do łez, była wysoce komunikatywna dla współczesnych kompozytorowi odbiorców, co stanowi najlepszy dowód, jak blisko związana była ze społeczeństwem, wśród którego powstawała" ${ }^{\circ 6}$.

Budowa części powolnej zdaje się już jednak wskazywać na znamiona nadchodzącego romantyzmu. Nie jest to już forma wariacyjna, tak ceniona przez rodzimych twórców symfonii z XVIII wieku, ale trzyczęściowa forma pieśni.

Menuetto Allegro, trzecia część symfonii, jest utrzymany w tonacji zasadniczej w takcie 3/4. Zaczyna się nietypowo na drugiej ćwierćnucie w takcie. Inicjalna struktura jest stopniowo nadbudowywana. Pierwszy motyw (repetowany dźwięk) wprowadzają początkowo instrumenty smyczkowe, klarnety i fagoty, w drugim takcie dołącza obój I, następnie flety i obój II. W takcie czwartym rozbrzmiewa już tutti. Menuet rozpoczyna się w dynamice forte. Pierwsza cząstka (a) obejmuje 12 taktów ujętych w znaki repetycji. Nie ma tu żadnych wyrazistych cech, co zresztą było charakterystyczne dla wielu XVIII-wiecznych menuetów. Podobnie jest w kolejnym odcinku (b), w którym kompozytor wykorzystuje motywy pierwszej cząstki. Odcinek pierwszy zostaje zakończony na tonice, natomiast drugi ma charakter modulujący - najpierw brzmi dominanta nonowa bez prymy i kwinty wtrącona do toniki szóstego stopnia, następnie Elsner stosuje progresyjne przesunięcie czterotaktu o sekundę w dół. Pojawia się dominanta z noną małą bez prymy i kwinty wtrącona do dominanty. Po 34 taktach wraca cząstka $a$. Całość zostaje zamknięta w 46 taktach, przy czym zarówno $a$, jak i $b a$ ujęte są w znaki powtórzenia. Bardzo ciekawe jest Trio, które już od pierwszych nut wyraźnie nawiązuje do polskiej muzyki ludowej. Melodii prowadzonej przez flet piccolo i skrzypce I towarzyszą jednostajne - chciałoby się powiedzieć - ,pociągnięcia smyka" w wykonaniu reszty zespołu smyczkowego, a także stojące dźwięki rogów. Pojawienie się melodii poprzedzają dwa takty akompaniamentu, nadającego równomierny rytm. Melodia przez dwa takty „krąży w kółko”, dążąc do kadencji, po czym w następnym czterotakcie schemat się powtarza, zmienia się tylko linia melodyczna w samej kadencji.

Charakterystyczny wstęp, rodzaj melodyki i akompaniamentu są tak wyrazistym przykładem użycia elementów polskiego folkloru, iż nie ulega wątpliwości,

\footnotetext{
${ }^{56}$ A. Nowak-Romanowicz, Wstęp, [w:] Elsner, Sumariusz ..., s. 20.
} 
że symfonia należy do tych dzieł Elsnera, w których łączy on upodobanie do muzyki klasyków wiedeńskich z pierwiastkami narodowymi, polskimi. Podobnie jak w innych częściach, tak i tu, w kolejnej cząstce Tria, nie pojawia się od razu nowa myśl, ale są przetwarzane motywy cząstki pierwszej. Jak wspomniano powyżej, Elsner był już kompozytorem, który operował pracą motywiczną i tematyczną. Była to integralna i charakterystyczna część jego warsztatu kompozytorskiego. To ważny moment, dlatego warto go podkreślić kolejny raz, ponieważ tylko kilku rodzimych kompozytorów symfonii działających na terenach polskich w XVIII oraz na przełomie XVIII i XIX wieku było zainteresowanych tym sposobem opracowywania materiału muzycznego i radziło sobie z pracą motywiczną oraz tematyczną.

Wyraźnie wyodrębniają się też tak charakterystyczne dla polskiej muzyki ludowej zakończenia „na dwa”, a więc na słabej części taktu. Przenikliwe brzmienie fletu piccolo dodaje wyrazistości linii melodycznej w dwóch skrajnych cząstkach (a); w cząstce $b$ blok instrumentów smyczkowych jest przeciwstawiony zespołowi instrumentów dętych. Ich brzmienia się nie stapiają, ponieważ prezentują one materiał muzyczny po kolei, a nie jednocześnie.

W Symfonii C-dur zarówno pierwsza, jak i ostatnia część wykazują znamiona formy sonatowej. Poszczególne cząstki formy sonatowej w pierwszej części symfonii są proporcjonalnie długie i ekspozycja nie dominuje już nad przetworzeniem i repryzą. Część finałowa ma bardziej skomplikowaną budowę i stanowi skrzyżowanie dwóch form. Przez Elsnera została ona określona jako Rondo. Ogniwo to jest utrzymane w tonacji zasadniczej w takcie 2/4. Splatają się tu forma sonatowa i rondo. Temat główny formy sonatowej jest jednocześnie refrenem ronda, temat drugi to pierwszy kuplet. „Nowa myśl” przetworzenia pełni rolę drugiego kupletu, przy czym materiał ten jest poddawany różnorodnym przekształceniom. Schemat tej części rozpisała Alina Nowak-Romanowicz:

Ekspozycja: Refren (A) C-dur - temat pierwszy + Epizod (B) G-dur - temat drugi + Refren (A1) C-dur - myśl końcowa;

Przetworzenie: Epizod (C) a-moll - nowa myśl + Refren (A2) F-dur, g-moll, d-moll, G-dur;

Repryza: Epizod (B) C-dur - temat drugi + Refren (A) - temat pierwszy + Coda $^{57}$.

${ }^{57}$ Zdaniem Aliny Nowak-Romanowicz najsilniejsze wpływy polskiej muzyki ludowej można odnaleźć w Trio Menueta oraz w części finałowej. W Menuecie pojawiają się rytmy mazurkowe. Podobny środek zastosował Elsner w Septecie z około 1830 roku (analogiczne zastosowanie rytmów mazurka można odnaleźć w utworach uczniów Elsnera - w Kwartecie op. 8 i Symfonii op. 15 Ignacego Feliksa Dobrzyńskiego oraz w Sonacie c-moll op. 4 Fryderyka Chopina), natomiast w Rondzie pojawia się refren/temat o rytmach krakowiaka, który - podobnie do refrenu z Rondo a la Krakowiak - jest wyraźnym nawiązaniem do arii z pierwszego aktu Krakowiaków i Górali Jana Stefaniego. 
Symfonia C-dur to jedna z tych symfonii rodzimych twórców, w których najsilniej zaznaczają się wpływy stylu klasyków wiedeńskich, zarówno na gruncie budowy formalnej, użytych środków, w tym instrumentacji, jak i w zakresie samej idei dzieła, wzbogaconego o elementy muzyki popularnej, ludowej.

\section{Przedstawiciel klasycyzmu i nurtu narodowego}

W polskiej muzykologii uznaje się Elsnera za przedstawiciela klasycyzmu. Opinia ta wydaje się uzasadniona, ponieważ z pewnością czerpał on wzorce z klasycyzmu wiedeńskiego, czego dowodem może być choćby przedstawiona powyżej analiza Symfonii C-dur. Autorzy raczej zgodnie przyznają, że przejawy tego stylu są widoczne przede wszystkim w jego twórczości instrumentalnej. Do muzykologów, którzy uznali, iż Elsner był głównym przedstawicielem klasycyzmu w muzyce polskiej, należeli Chomińscy. Podkreślają oni:

„Podobnie jak w muzyce zachodnioeuropejskiej, z przejawami klasycyzmu spotykamy się głównie $\mathrm{w}$ wielkich formach instrumentalnych symfonii, sonacie, koncercie, uwerturze, w formach kameralnych i polifonicznych, szczególnie w fudze" ${ }^{" 58}$.

Także według Aliny Nowak-Romanowicz Józef Elsner był głównym przedstawicielem klasycyzmu w polskiej muzyce symfonicznej, a jego Symfonia $C$-dur stanowi niezwykle istotny etap kształtowania się i stabilizacji zarówno środków klasycznych na ziemiach polskich, jak i polskiego stylu narodowego. W porównaniu z XVIII-wiecznymi symfoniami polskimi Elsner miałby - zdaniem autorki - osiągnąć etap niemal pełnej stabilizacji środków klasycznych. Alina Nowak-Romanowicz przyznaje jednak, że

„wykorzystywanie zdobyczy klasyków wiedeńskich i ingresja elementów klasycyzmu osiągnie swe apogeum w Symfonii op. 15 z roku 1834 ucznia Elsnera, uzdolnionego symfonika Ignacego Feliksa Dobrzyńskiego"s9.

Według autorki trudno porównywać dokonania Elsnera na polu pracy motywicznej i tematycznej w przetworzeniach z osiągnięciami klasyków wiedeńskich. Por. A. Nowak-Romanowicz, Klasycyzm 1750-1830, [w serii:] Historia muzyki polskiej, red. S. Sutkowski, t. 4, Warszawa 1995, s. 54 i nast.

${ }^{58}$ J. M. Chomiński, K. Wilkowska-Chomińska, Historia muzyki polskiej, cz. 1, Kraków 1995, S. 225.

${ }^{59}$ A. Nowak-Romanowicz, Wstęp, [w:] Józef Elsner (1769-1854), Symfonia, [w serii:] Symfonie polskie, z. 10, red. Z. M. Szweykowski, Kraków 1986, s. VII. Warto na marginesie wspomnieć, iż uczniowie Elsnera chętnie przejmowali od niego to specyficzne skrzyżowanie elementów stylu 
Elsner łączył elementy stylu wiedeńskiego z pierwiastkami polskiej muzyki ludowej. Dosłowne cytowanie wątków ludowych stopniowo przybierało u niego formy nieco bardziej stylizowane, bardziej artystyczne. O ile ten dojrzały warsztat charakteryzuje jego późniejsze dzieła, które w większości były wokalno-instrumentalne, o tyle w utworach instrumentalnych, które powstawały raczej we wcześniejszej fazie twórczości, można odnaleźć nieco bardziej dosłowne zapożyczenia z tańców i pieśni.

Dość zagadkowo rysuje się brak zainteresowania Elsnera nurtem symfonii programowej związanej z ważnymi wydarzeniami historycznymi. Jego ogromne zaangażowanie $\mathrm{w}$ sprawę pielęgnowania polskości i podtrzymywania ducha w zniewolonym narodzie zdawały się wystarczającym pretekstem do tworzenia także utworów symfonicznych w tym nurcie. Wydaje się jednak, że czerpanie $\mathrm{z}$ polskiego folkloru było w przekonaniu Elsnera dostatecznie silnym środkiem wyrazu, świadczącym o narodowym charakterze utworów symfonicznych. Działający w czasach Elsnera Karol Kurpiński stworzył symfonię programową Bitwa pod Możajskiem (późniejsza Wielka symfonia bitwę wyrażająca), a Józef Deszczyński symfonię Bitwa pod Itawa Pruska. W podobnym czasie została też skomponowana Pavla Vranický'ego Grande Symphonie caractéristique pour la Paix avec la République françoise (Symfonia charakterystyczna, wystawiająca pokój z Republika Francuska) op. 31. Elsner natomiast prawdopodobnie nie uznawał programowości i zdecydowanie wolał bardziej tradycyjną postać symfonii, pozbawioną programu pozamuzycznego, choć oczywiście symfonie ilustrujące określone treści były już znane i tworzone także w XVIII wieku. Nie bez znaczenia pozostaje fakt, iż w XIX wieku gatunek symfonii już go niemalże nie interesował. Chociaż prawie cała jego twórczość symfoniczna zaginęła, można przypuszczać, że stylistycznie wpisywała się ona zapewne we wzorce klasycyzmu wiedeńskiego - oczywiście w postaci, jaką można odnaleźć u Haydna czy Mozarta. Nie wydaje się bowiem, aby symfonie Beethovena - które doskonale znał - zainspirowały go jako twórcę. Nie wiadomo, jaki kształt miała ostatnia symfonia Elsnera, ale została ona stworzona na potrzeby wykonania szkolnego i w tej sytuacji raczej nieuzasadnione jest przyjęcie tezy, iż było to dzieło o walorach nowatorskich.

klasycznego ze stylem narodowym. W pierwszym rzędzie trzeba tu wymienić Ignacego Feliksa Dobrzyńskiego (1807-1867). Co prawda w stosunku do warsztatu swojego mistrza rozwinął on środki techniczne, stosował już pracę tematyczną nie tylko w przetworzeniu, ale wprowadzał jej elementy także w ekspozycji, stosował elementy techniki polifonicznej oraz integrację motywiczną symfonii, jednakże przejął od Elsnera nade wszystko postawę etyczną i poczucie misji (artysty narodowego), a także powolny wstęp na początku symfonii, powiązanie motywiczne tematów formy sonatowej, zastosowanie w menuecie (choć nie tylko) elementów polskiej muzyki ludowej oraz skrzyżowanie w części finałowej formy sonatowej i ronda. 
Czas, w którym Elsner komponował, obejmował wiele dziesięcioleci, ale tak szybkie wygaśnięcie zainteresowania symfonią zdaje się przemawiać za tezą, że na gruncie tego gatunku raczej nie nastąpiła w jego twórczości ewolucja stylistyczna. Zapewne osiągnął on tylko większą dojrzałość jako twórca i w kolejnych latach bardziej pewnie, bardziej świadomie operował środkami technicznymi niż w młodzieńczych utworach z okresu wrocławskiego. W tej sytuacji zasadne jest uznanie zachowanej Symfonii C-dur za miarodajne źródło, na podstawie którego można wysuwać tezy o kształcie symfoniki tego twórcy.

Nie ulega wątpliwości, że okres, w którym powstawały symfonie Elsnera, nie może być jeszcze określony jako romantyczny; sam muzyk zaś, choć niezwykle zasłużony dla polskiej kultury, jako kompozytor nie należał do grona tych twórców, którzy rewolucjonizowali język muzyczny, toteż nie należy się w jego utworach symfonicznych dopatrywać znamion nowej epoki. Uprawnione wydaje się uznanie jego symfonii za zamknięcie historii tego gatunku w jego XVIII-wiecznym kształcie na ziemiach polskich. Przyjmując takie kryteria i zaliczając skomponowaną w 1805 roku Symfonię C-dur do dzieł klasycznych, ale w przedbeethovenowskim kształcie, charakterystycznym dla minionego stulecia, można uznać, iż należy ona do najbardziej dojrzałych dzieł symfonicznych rodzimych twórców.

Małgorzata Kowalska, definiując czasy, w jakich działał i tworzył Elsner, stwierdza, że

„W historiografii muzycznej stosowano dla tego okresu rozmaite nazwy, np. «oświecenie», «wczesny romantyzm», «preromantyzm», «przedświt romantyzmu», ponieważ termin «klasycyzm» w polskiej historiografii muzycznej był jeszcze do niedawna słabo rozpowszechniony" ${ }^{\text {"60 }}$.

Terminu „klasycyzm” używała Alina Nowak-Romanowicz, która w tytule swojej książki określiła jego ramy czasowe na ziemiach polskich na lata 1750$-1830^{61}$. Stosowali go także Józef M. i Krystyna Chomińscy ${ }^{62}$. Jeżeli przyjmie się perspektywę polskiego klasycyzmu, który miałby trwać do 1830 roku, to po-

\footnotetext{
${ }^{60}$ Autorka ta twierdzi, iż „O ile w Niemczech nastanie XIX w. oznaczało gwałtowne przemiany w świadomości twórców, wyrażające się zaistnieniem prądu romantycznego w sztuce, o tyle w polskiej kulturze muzycznej pierwszych dekad XIX stulecia trwał klasycyzm przynajmniej w zakresie stylu i preferowanych form muzycznych. Okres, w jakim przyszło Elsnerowi podjąć działania twórcze, to typowy okres przejściowy, pełen niepokoju, pozbawiony stabilności stylistycznej. W zakresie kultury muzycznej sytuacja w Polsce (!) pod koniec XVIII w. i na początku XIX w. przedstawiała się bardzo niekorzystnie. Decydowały o tym przede wszystkim: brak muzyków profesjonalnych oraz nieprzygotowany odbiorca". Kowalska, op. cit., s. 364.

${ }^{61}$ Nowak-Romanowicz, Klasycyzm...

${ }^{62}$ Chomiński, Wilkowska-Chomińska, op. cit., s. 225.
} 
równanie wypadnie na korzyść kolejnego pokolenia twórców, jednakże jak się wydaje można porównywać symfonie Elsnera do dzieł kompozytorów XVIII-wiecznych, ponieważ jego styl symfoniczny nie wpisuje się w kolejne stulecie.

Symfonia C-dur Elsnera to utwór o czteroczęściowym układzie i klasycznej obsadzie. Nawiązania do polskiego folkloru są wyraźne, co odpowiada praktyce wplatania elementów muzyki popularnej czy ludowej w dziełach wiedeńskich mistrzów. Elsner starał się odchodzić od pewnych manier typowych dla wcześniejszych stylów XVIII wieku na rzecz prostoty wyrazu i szczerości wypowiedzi. Z pewnością jednak nie było to dla niego zadanie łatwe i niejednokrotnie można zaobserwować zmaganie się z tkanką muzyczną. Wyrazistym tego przykładem są pojawiające się w Symfonii C-dur odcinki, które można określić jako puste wyrazowo, a więc na przykład wielokrotne powtarzanie ostatniego akordu na przestrzeni kolejnych taktów kadencji, co wydaje się nawiązaniem do praktyki operowej, czy też - także typowe dla kadencji - wielokrotne naprzemienne stosowanie określonego typu połączenia, na przykład ulubionej przez Elsnera dominanty nonowej bez prymy i jej rozwiązania na tonikę.

Przejawem muzyki XVIII-wiecznej w jej przedklasycznej postaci jest też upodobanie do stosowania krótkich motywów, a nie szerzej zakrojonej linii melodycznej. Zdecydowanie najbardziej udane są fragmenty nawiązujące do muzyki ludowej, w których linia melodyczna rozwija się w nieskrępowany, spontaniczny sposób. Elsner z dużą łatwością korzystał z bogactwa polskiej kultury muzycznej. Wiadomo, że chciał, aby wszyscy uszanowali to, iż jest Polakiem z wyboru, ale Symfonia C-dur wskazuje jeszcze na to, że nie tylko sercem i rozumem przynależał do tej kultury - także jego warsztat kompozytorski zdecydowanie zyskiwał wtedy, kiedy czerpał ze skarbnicy polskiego folkloru. Wydaje się, że odcinki „ludowe” są najbardziej zgrabnymi i udanymi fragmentami Symfonii $C$-dur. To w nich przede wszystkim ujawnia się wspomniana wcześniej szczerość wypowiedzi. Proste, bezpretensjonalne, nieobarczone manierą operową, ujmują słuchacza swoim pięknem.

Trudno ocenić, czy gdyby Elsner był zainteresowany tym gatunkiem w dojrzałym okresie swej twórczości, kiedy był już bogatszy o nowe doświadczenia, wynikające z kontaktu z symfoniami Beethovena i pierwszych romantyków, to miałby szanse stworzyć podwaliny XIX-wiecznej symfoniki polskiej. Wydaje się to mało prawdopodobne, ponieważ mimo pewnej zmiany poglądów na muzykę instrumentalną pod koniec życia jednak największą wagę przywiązywał do twórczości wokalno-instrumentalnej, która w jego przekonaniu najlepiej służyła sprawie narodowej. Zapewne, mimo pewnych cytowanych wcześniej deklaracji, podświadomie wierzył, że dopiero muzyka wsparta słowem niesie prawdziwy przekaz ideowy. Z tego też względu rozwój samych środków muzycznego wyra- 
zu (tj. bez warstwy tekstowej i bez udziału głosu ludzkiego) - a takowy zapewnił nieśmiertelność zarówno jego niemalże rówieśnikowi, Beethovenowi, jak i jego uczniowi, Chopinowi - nie był dla niego osiągalny w takiej mierze, jakiej wymagała muzyka instrumentalna XIX wieku. Elsner dostrzegał przemiany, ale chyba do końca życia podchodził do nich dość nieufnie, z typowo oświeceniowym dystansem; dlatego też tym bardziej zasadne jest przypisanie jego utworów symfonicznych do stylistyki XVIII wieku w jej wiedeńskim kształcie.

\section{Na tle biografii}

Na zakończenie warto przyjrzeć się biografii Elsnera, wgląd bowiem w jego życiorys pozwala odnaleźć pewne wskazówki, dlaczego kompozytor już w tak młodym wieku zainteresował się gatunkiem symfonii.

Józef Antoni Franciszek Elsner żył w latach 1769-1854. Urodził się w Grodkowie na Śląsku Opolskim. W nowszych opracowaniach określa się go jako Ślązaka ${ }^{63}$, odchodząc od przyjętego w dawnych publikacjach przypisywania mu narodowości niemieckiej ${ }^{64}$. Problem $\mathrm{z}$ dookreśleniem jego pochodzenia, owo „cudzoziemstwo” Elsnera, ma długą tradycję, ponieważ podkreślał je jego rywal, Karol Kurpiński, szczycący się polską, nobilitującą końcówką „-ski”"65. Jako Niemca potraktował Elsnera na przykład Aleksander Poliński ${ }^{66}$, a Zdzisław Jachimecki dodatkowo podkreślał, w jak bardzo niemieckim i niechętnym Polsce otoczeniu został on wychowany ${ }^{67}$.

Hanna Pomorska, poza uwagami o niemieckim wychowaniu, przytoczyła także legendę o rzekomych szlacheckich korzeniach rodu Elsnera. Jego przodkami mieliby być szwedzcy emigranci z czasów Karola XII ${ }^{68}$. Według Aliny Nowak-Romanowicz źródłem tej legendy miał być sam kompozytor, a rozpowszechnił ją przede wszystkim Wojciech Bogusławski, co spowodowało dodatkowe kom-

${ }^{63}$ Zob. M. Zduniak, Józef Elsner-syn Śląska Opolskiego, [w:] Józef Elsner (1769-1854). Życie - działalność - epoka..., s. 15-42, tu: s. 15; eadem, Autografy, rękopisy i druki dziet Józefa Elsnera w bibliotece kapitulnej we Wrocławiu, [w:] ibid., s. 155.

${ }^{64} \mathrm{Na}$ domu, w którym urodził się Elsner, wisi obecnie tablica: „W tym domu urodził się | w roku 1769 | syn Opolszczyzny | Józef Elsner | wielki muzyk | i nauczyciel Chopina”. M. Pajchert-Flis, Recepcja twórczości Józefa Elsnera w XX wieku ze szczególnym uwzględnieniem środowisk Opola i Wroctawia, [w:] ibid., s. 349.

${ }^{65}$ Kowalska, op. cit., s. 366.

${ }^{66}$ A. Poliński, Dzieje muzyki polskiej w zarysie, Lwów 1907, s. 186.

${ }^{67}$ Z. Jachimecki, Muzyka polska w rozwoju historycznym od czasów najdawniejszych do doby obecnej, t. 1, cz. 2: Wiek XVIII do połowy wieku XIX, Kraków 1951, s. 134.

${ }^{68}$ H. Pomorska, Józef Elsner, Łódź 1948, s. 1. 
plikacje, ponieważ zaczęto Elsnerowi przypisywać imiona Józef Ksawery zamiast Józef Antoni Franciszek ${ }^{69}$. Obecnie pojawiają się publikacje, w których podkreśla się kontakty Elsnera w wieku młodzieńczym z polską kulturą, głównie kościelną ${ }^{70}$, podtrzymując tezę o śląskim pochodzeniu muzyka i wynikających stąd komplikacjach, związanych z historią tych ziem i zamieszkującej je ludności.

Z symfonią Elsner zetknął się prawdopodobnie już w dzieciństwie. W latach 1775-1781 uczęszczał on w swojej rodzinnej miejscowości do szkoły powszechnej. Jako uczeń należał wtedy do chóru kościelnego, uczestnicząc czynnie w muzycznej oprawie nabożeństw. Z badań nad kulturą muzyczną w XVIII wieku wynika, że w kościołach katolickich symfonie rozbrzmiewały zarówno z okazji wszelkiego typu świąt i uroczystości, jak i podczas zwykłych mszy ${ }^{71}$. Powszechną praktyką było wykonywanie tego rodzaju utworów przed nabożeństwem, ewentualnie także po nim. Kościoły, a szczególnie klasztory, miały niejednokrotnie własne kapele, ale nawet jeśli nie zatrudniały kapelistów, to i tak chętnie wynajmowano muzyków, żeby uświetniali swoją grą uroczyste msze. Kultura muzyczna ówczesnych ziem polskich była najbliższa kulturze tych ośrodków niemieckojęzycznych, w których panowała religia katolicka (pierwszy kościół ewangelicki w Grodkowie oddano do użytku dopiero w roku 1786, a więc już po wyjeździe Elsnera ${ }^{72}$ ). Struktura ludności Śląska sprawiała jednak, iż nie tylko podobieństwa, lecz także związki między kulturą polską a śląską były jeszcze wyraźniejsze. Można więc założyć, że mały Elsner miał już w swojej rodzinnej miejscowości okazję słuchać symfonii, stąd ten gatunek wydawał mu się wyjątkowo bliski w młodzieńczych latach.

Muzyka wykonywana w kościele wywarła na chłopcu ogromne wrażenie. Ten typ twórczości będzie mu do końca życia bardzo bliski, a jego związki z Kościołem katolickim pozostaną na zawsze bardzo silne. Istnieją dowody, iż brał on udział w nabożeństwach, w czasie których brzmiały - jak to określał - „słowiańskie śpiewy". Elsner pisał wiele lat później:

${ }^{69}$ A. Nowak-Romanowicz, Józef Elsner. Monografia, Kraków 1957, s. 11 i nast.

${ }^{70}$ Zduniak, Józef Elsner..., s. 16 i nast.

${ }^{71}$ Zob.: B. Stróżyńska, Symfonia, sonata czy andante? Nieporozumienia terminologiczne w XVIII-wiecznej muzyce instrumentalnej na przykładzie utworów pro processione Marcina J. Żebrowskiego, „Polski Rocznik Muzykologiczny” 6: 2007-2008, s. 119-140; eadem, Rozważania o symfonii kościelnej i symfonii w kościele na podstawie XVIII-wiecznych utworów polskich zachowanych w Archiwum OO. Paulinów na Jasnej Górze - referat z Międzynarodowej Konferencji Muzykologicznej Związku Kompozytorów Polskich Karol Szymanowski i świat jego wartości w 125. rocznice urodzin $i$ 70. rocznice śmierci kompozytora, Zakopane - Kraków, 19-22 października 2007; eadem, Utwory pro processione Marcina Józefa Żebrowskiego, [w:] Marcin Józef Żebrowski (XVIII w.). Kompozytor i muzyk kapeli jasnogórskiej, red. R. Pośpiech, Opole 2013, s. 97-120.

${ }^{72}$ Zduniak, Józef Elsner..., s. 16. 
„Temat główny wzięty ze słowiańskiego śpiewu kościelnego, a śpiewanego z takim wzruszeniem przez ojca mego, gdy brał udział w ogólnym śpiewie kościelnym, że na mnie, wówczas młodym chłopcu, tak nadzwyczajne wrażenie sprawił, że do dziś dnia pamiętam następujące takty"ᄁ3.

Według Marii Zduniak z owymi polskimi śpiewami miałby się stykać w kościele Wniebowzięcia NMP ${ }^{74}$.

Z domu rodzinnego w Grodkowie na Śląsku Opolskim Elsner wyjechał już w wieku jedenastu lat. Od 1781 roku pobierał nauki w przyklasztornej szkole dominikanów we Wrocławiu, później uczęszczał tam do gimnazjum jezuickiego św. Macieja oraz do Akademii Leopoldyńskiej. Miasto to było prężnym ośrodkiem kulturalnym, w którym chłopiec miał szansę poznawać twórczość ówczesnych kompozytorów jako słuchacz i jako wykonawca; na przykład w wieku szesnastu lat, 25 marca 1785 roku, wykonał w kościele św. Elżbiety solową partię w oratorium pasyjnym Der Tod Jesu Carla Heinricha Grauna. Występował nie tylko jako śpiewak solista, lecz także jako skrzypek kameralista; zarabiał, występując w teatralnym chórze lub grając na skrzypcach w kapeli. Miał wtedy kontakt na przykład z dziełami Haendla ${ }^{75}$, Haydna, Mozarta, Dittersdorfa. Warto zaznaczyć, że Dittersdorf był obok Haydna i Pleyela twórcą, którego symfonie były najbardziej cenione na ziemiach polskich, co można stwierdzić na podstawie analizy zasobów rodzimych archiwów. Wiadomo też, iż mimo oficjalnych dokumentów jego muzyka o charakterze świeckim rozbrzmiewała między innymi w europejskich kościołach, stanowiąc ogromną atrakcję dla wiernych ${ }^{76}$. Dittersdorf wspomina w autobiografii, że występował we włoskich kościołach, grając m.in. koncerty skrzypcowe w czasie mszy, a kiedy władze Kościoła zorientowały się, jak wiele osób przychodzi go słuchać, to same prosiły go o granie koncertów. Można

${ }^{73}$ Elsner, Sumariusz ..., s. 41.

${ }^{74}$ Zduniak, Józef Elsner ..., s. 16. Jako niespełna osiemdziesięcioletni mężczyzna zacytował jeszcze Elsner polską pieśn religijną Panie, kocham Cię w oratorium Stabat Mater op. 93.

${ }^{75} \mathrm{~W}$ maju 1788 roku w kościele św. Marii Magdaleny we Wrocławiu wykonano po raz pierwszy Mesjasza Haendla pod dyrekcją Adama Hillera. W wykonaniu tym uczestniczyły chór i orkiestra złożona z 250 osób. Maria Zduniak przypuszcza, iż Elsner brał udział w tym wielkim wydarzeniu jako chórzysta lub skrzypek. M. Zduniak, Die Aufführungen von Georg Friedrich Haendels Oratorium „Messias” im 18. und 19 Jahrhundert in Breslau, „Haendel-Jahrbuch” 48: 2002, s. 209-219.

${ }^{76}$ W konstytucjach papieża Benedykta XV z 19 lutego 1794 roku można przeczytać: „W końcu co się tyczy symfonii można je cierpieć tam, gdzie są one we zwyczaju, byle tylko były poważne i długością swoją nie nudziły słuchaczy" (według: ks. A. Nowowiejski, Śpiew liturgiczny, muzyka i chóry kościoła katolickiego, Warszawa 1885, s. 60; cyt. [za:] T. Strumiłło, Do dziejów symfonii polskiej, „Muzyka” 1953 nr 5-6, s. 28. 
założyć, iż zetknięcie się z dziełami tego tak lubianego wówczas kompozytora wywarło także na młodym Józefie duże wrażenie.

We Wrocławiu chłopiec znów miał kontakt z polską kulturą. Na pewno bywał w kościele św. Wita, w którym odbywały się polskie nabożeństwa i msze. Tam wykonywano jego utwory kościelne, co opisywał w Sumariuszu:

„[...] wykonany został w całości jako oratorium pod dyrekcją rektora szkół, p. Schoen, w Wielką Sobotę rano w małym kościele, w którym grób Zbawiciela był zawsze wystawiany i gdzie jeszcze za moich czasów w polskim języku kazano" ${ }^{\text {"77 }}$.

Zapewne nie tylko życie koncertowe Wrocławia, lecz także oprawa mszy, która zwyczajowo wiązała się często $\mathrm{z}$ wykonywaniem symfonii, mogły wpływać na fakt, że to właśnie ten gatunek był tak bliski Elsnerowi już wtedy, kiedy zaczynał swoją przygodę z tworzeniem muzyki.

Chłopiec bardzo wcześnie zaczął próbować swoich sił na polu kompozycji. Jego motet Ave Maria rozbrzmiewał w kościele św. Wojciecha we Wrocławiu już w 1782 roku, wtedy więc, kiedy kompozytor miał zaledwie trzynaście lat. We Wrocławiu powstało też kilka jego pierwszych symfonii, o czym sam napisał później w Sumariuszu, surowo - jak już powiedziano - oceniając te wczesne prace. Opuścił Wrocław w dwudziestym roku życia, a to oznacza, że symfonie tworzył już w wieku kilkunastu lat.

Elsner niełatwo odnalazł w życiu swoje powołanie. Na życzenie rodziców we Wrocławiu rozpoczął najpierw studia teologiczne, postanowił jednak, że nie poświęci się stanowi duchownemu, ponieważ bardziej zainteresowała go medycyna $^{78}$. Chęć zostania lekarzem była tak silna, że Grodków ufundował mu stypendium, aby mógł kontynuować studia medyczne w Wiedniu, dokąd się udał w 1789 roku. Wiedeń tych czasów stanowił potężny ośrodek muzyki symfonicznej i młodzieniec na pewno miał tam szanse częstego kontaktu $\mathrm{z}$ tego typu utworami. Peter Andraschke twierdzi, iż w Wiedniu jego zainteresowania obejmowały wiele gatunków muzycznych. Autor przeprowadza między innymi analizę koncertów, które były organizowane w czasie pobytu Elsnera w tym ośrodku, podkreślając bogactwo życia muzycznego na dworze, w salach koncertowych, teatralnych, w prywatnych domach oraz kościołach. Andraschke wymienia wielkie osobowości współtworzące w latach 1789-1791 życie muzyczne Wiednia ${ }^{79}$.

${ }^{77}$ Elsner, Sumariusz ..., S. 31.

${ }^{78}$ Zduniak, Józef Elsner..., s. 18.

${ }^{79}$ Warto podkreślić powszechną wówczas praktykę, która dotyczyła też Wiednia, iż w szczególnych momentach roku (jak np. w adwencie) nie grano przedstawień, ale za to odbywały się 
Długa choroba skłoniła Elsnera do refleksji. Po przemyśleniach i ostatecznej zmianie decyzji o wyborze zawodu w 1791 roku pojechał do Brna z zamiarem poświęcenia się tylko muzyce. W mieście tym działał od jesieni 1791 do wiosny 1792 roku $^{80}$. Został skrzypkiem w orkiestrze teatralnej, ale już w kolejnym roku przeniósł się do Lwowa, gdzie objął stanowisko kapelmistrza w teatrze. Z miastem tym związał swe losy na nieco dłużej, pozostając tam do roku 1799.

Okres lwowski okazał się bodaj najważniejszy dla ukształtowania postawy młodego Elsnera, zarówno twórczej, jak i życiowej. Od momentu, kiedy Lwów stał się stolicą prowincji, a więc po pierwszym rozbiorze Polski w 1772 roku, życie kulturalne tego miasta nabrało ogromnego rozmachu. Organizowano liczne koncerty i przedstawienia teatralne. Ściągnęło tam bardzo wielu mieszkańców Wiednia, którzy uznali, że jest to doskonała okazja do zrobienia interesów. Z zachowanych, choć nieco późniejszych, relacji można wnioskować, iż ludność Lwowa między innymi w muzyce i wszelkiego typu zabawach szukała zapomnienia, uciekając $w$ ten sposób od refleksji o tragicznej sytuacji ojczyzny ${ }^{81}$. Nie oznacza to jednak, że w mieście nie pielęgnowano polskiego ducha. W tym czasie wystawiano tam na przykład Agatke, czyli przyjazd Pana Jana Dawida Hollanda oraz Cud mniemany, czyli Krakowiacy i Górale Jana Stefaniego. Dla Elsnera folklor polski okazał się tak inspirujący, że od tego momentu zaczął go świadomie wplatać do swoich kompozycji.

Luba Kijanowska-Kamińska i Lidia Melnyk twierdzą, iż

„właśnie patriotyczna atmosfera lwowska i panujący tutaj powszechny entuzjazm narodowy miały decydujący wpływ na przestawienie się Elsnera na tory polskie. Właśnie we Lwowie został po raz pierwszy prawdziwym kompozytorem polskim" ${ }^{\prime 2}$.

\footnotetext{
koncerty, w czasie których chętnie wykonywano właśnie symfonie. P. Andraschke, Joseph Elsner und Wien, [w:] Józef Elsner (1769-1854). Życie - działalność - epoka ..., s. 88.

${ }^{80}$ P. Koukal, Handschriften und Drucke der Musikwerke von Józef Elsner in Böhmen und Mähren, [w:] ibid., s. 171.

${ }^{81}$ „Karnawał w tym roku był tem huczniejszy, iż pół Warszawy bawiło w murach Lwowa. Mnóstwo rodzin bogatych z za kordonów szukało w naszem mieście zapomnienia po świeżo doznanych klęskach i upokorzeniach. [...] Wśród wesołego gwaru nikt głosu nie podniósł w sprawie poważniejszej, ogólne dobro mającej na celu; zapomniano o przeszłości, nie troszczono się wcale o przyszłość. Bawiono się tylko bez końca, szalano gdyby za saskich czasów". S. Schnür-Pepłowski, Bogusławski we Lwowie (Ustęp z dziejów sceny polskiej), Lwów 1895, cyt. [za:] Luba Kijanowska-Kamińska, Lidia Melnyk, Józef Elsner a kultura muzyczna Lwowa, [w:] Józef Elsner (1769-1854). Życie - działalność - epoka..., s. 98.

${ }^{82}$ Ibid., s. 101.
} 
Według relacji Stanisława Schnür-Pepłowskiego:

„Elsner, Niemiec z urodzenia, był... kapelmistrzem tutejszej opery niemieckiej, lecz za przybyciem Bogusławskiego szczerze zajął się naszą sztuką. W ciągu kilku miesięcy nauczył się po polsku i począł komponować dla polskiego teatru, choć mu to przychodziło zrazu z trudnością. Nad każdem polskim słowem pisał pedantyczny Niemiec odpowiedni wyraz niemiecki" $"$.

Alina Nowak-Romanowicz twierdzi, że Lwów był najbardziej prężnym ośrodkiem koncertowym po pierwszym zaborze Polski. Już w latach 1784-1796 organizowano w tym mieście liczne koncerty. Później rozpoczął tam działalność Józef Elsner, który zdaniem autorki był czołowym organizatorem koncertów na ziemiach polskich w okresie klasycyzmu. Założona przez niego w 1796 roku Akademia Muzyczna miała na celu przede wszystkim działalność koncertową (zresztą Elsner nazwie ją po latach w Sumariuszu także Akademią Koncertową). Ponad wszelką wątpliwość można stwierdzić, iż pobyt Elsnera we Lwowie wiązał się ściśle z wykonywaniem i komponowaniem muzyki symfonicznej. Kijanowska-Kamińska i Melnyk podkreślają:

„Akademia nie była «zakładem» oświaty muzycznej, lecz organizacją koncertową, łączącą muzyków profesjonalnych (przede wszystkim należących do orkiestry miejskiej) oraz amatorów. Zbierali się każdego piątku na wspólne koncerty" ${ }^{\prime 4}$.

Autorki uważają, z czym się z pewnością należy zgodzić, że to właśnie dla Akademii zostały skomponowane: Symfonia D-dur z 1796 roku, Symfonia C-dur z tego samego roku oraz Symfonia Es-dur z roku $1797^{85}$. Także Reiss podkreślał znaczenie okresu lwowskiego dla twórczości symfonicznej Elsnera, przy czym uważał jeszcze, iż we Lwowie powstały cztery symfonie, podczas gdy Nowak-Romanowicz mówiła już tylko o trzech napisanych w tamtym okresie ${ }^{86}$.

Zgodnie z duchem tych czasów Akademia gromadziła profesjonalnych i nieprofesjonalnych miłośników muzyki, zarówno pochodzenia szlacheckiego, jak i mieszczan. Należeli do niej urzędnicy lwowscy oraz wszelkiego typu „znakomitości polskie". Nowak-Romanowicz wymienia wśród lwowskich znajomych Elsnera następujących muzyków: „dawny przyjaciel śpiewak Huss, doskonały

\footnotetext{
${ }^{83}$ Cyt. [za:] ibid., s. 100.

${ }^{84}$ Ibid., s. 102.

${ }^{85}$ Ibid.

${ }^{86}$ Ibid., s. 105.
} 
według słów Elsnera kontrabasista Gramczyński oraz altowiolista i kompozytor Wojciech Dankowski" ${ }^{87}$. Na piątkowych koncertach występowali m.in. Michał hr. Wielhorski (,grywał na skrzypcach koncerta Viottiego z dodaniem doń adagiów własnego utworu") i księżna Jabłonowska (w roli śpiewaczki) ${ }^{88}$. Elsner występował w roli kompozytora, dyrygenta i skrzypka. Z zachowanych programów można wnioskować, że Akademia działała między wrześniem 1796 a kwietniem 1797 roku. ${ }^{89} \mathrm{Na}$ otwierającym jej działalność koncercie 9 września 1796 roku wykonano dwie symfonie (Gyrowetza i Pleyela) ${ }^{90}$.

Trudno nie dostrzec związków między bardzo ożywioną działalnością koncertową Elsnera a jego bogatą twórczością instrumentalną z okresu lwowskiego. Organizując w tym mieście cotygodniowe koncerty Akademii Muzycznej, Elsner proponował słuchaczom zarówno swoje własne symfonie, jak i symfonie Josepha Haydna, Wolfganga Amadeusza Mozarta czy też Pavla Vranický'ego. Nie można obecnie stwierdzić, na ile styl innych twórców wpłynął na tego typu utwory stworzone przez Elsnera we Lwowie, gdyż jego symfonie z tego okresu się nie zachowały. Wydaje się jednak, że najbliższe prawdy będzie stwierdzenie, iż jego inspiracją w odniesieniu do utworów symfonicznych był styl wiedeński. Lwowskie utwory Elsnera ukazywały się drukiem, jednakże nie ma wśród nich symfonii, kompozytor bowiem wydawał głównie muzykę kameralną.

W roku 1795 dyrektorem teatru lwowskiego został Wojciech Bogusławski, z którym Elsner zawiązał współpracę, komponując też muzykę do jego tekstów. Z tego okresu zachowała się opera tych twórców Amazonki czyli Herminia. Poza polskimi operami spod pióra Elsnera zaczęły też wychodzić wspomniane utwory instrumentalne, w które wplecione były elementy polskiej muzyki ludowej. Stopniowo jednak zainteresowanie Elsnera muzyką symfoniczną słabło, ustępując miejsca twórczości wokalno-instrumentalnej. Bliska znajomość i współpraca z Wojciechem Bogusławskim, który w 1799 roku przekonał Elsnera do opuszczenia Lwowa i rozpoczęcia intensywnej działalność w Warszawie, okazała się bardzo ważna dla obu muzyków i niezwykle owocna dla kultury polskiej. Elsner zamieszkał na stałe w Warszawie latem 1799 roku. Został dyrektorem muzyki w Teatrze Narodowym i przez pół wieku prowadził w tymże teatrze operę. Wystawił w niej m.in. trzydzieści oper i dwa balety swojego autorstwa. W tym samym czasie w polskich czasopismach ukazywały się jego recenzje i artykuły. Elsner był też korespondentem „Allgemeine Musikalische Zeitung”, choć na te-

${ }^{87}$ Nowak-Romanowicz, Józef Elsner, [w serii:] Studia i materiaty..., s. 36.

${ }^{88}$ Ibid., s. 40.

${ }^{89}$ Nowak-Romanowicz, Klasycyzm ..., s. 48.

${ }^{90}$ Nowak-Romanowicz, Józef Elsner, [w serii;] Studia i materiaty..., s. 40; eadem, Klasycyzm..., s. 48. 
mat jego współpracy z tym pismem obecnie niewiele wiadomo. Lucian Schiwietz ustalił, iż Elsner jest autorem krótkiej notatki w „Allgemeine Musikalische Zeitung" O muzyce rosyjskiej, jego autorstwo jest też prawdopodobne w przypadku 24 innych tekstów publikowanych w tym piśmie ${ }^{91}$.

W Warszawie związki Elsnera z życiem koncertowym - w tym z symfoniką - nie słabły i przybierały różnorodne formy. Lwów był w czasie działalności koncertowej Elsnera pod zaborem austriackim, z kolei po przeniesieniu się do Warszawy muzyk ten trafił pod panowanie Prus. W obu miastach można odnotować ożywienie życia muzycznego, zarówno o charakterze narodowym, jak i ponad podziałami, łączącym miłośników muzyki pochodzenia polskiego oraz obcego. Od 1799 roku Elsner rozwijał działalność koncertową w Warszawie, współpracując między innymi z urzędnikami niemieckimi, którzy byli melomanami. Należał do nich na przykład Fryderyk Mosqua, który w 1800 roku zorganizował koncert w rocznicę śmierci Mozarta. W Warszawie pod zaborami kwitło życie koncertowe, ale największe nasilenie organizowania towarzystw muzycznych przypada już na pierwsze lata XIX wieku.

W 1801 roku zorganizowano w Warszawie Harmoniegesellschaft, towarzystwo, które spotykało się i muzykowało w niedzielne popołudnia; w 1804 roku do czołowych postaci warszawskiego życia muzycznego zaczął należeć Ernst Theodor Amadeus Hoffmann, który wraz z Mosquą zorganizował w 1805 roku Resursę Muzyczną, do której zaproszono wielu Polaków. Dzięki temu towarzystwu ożywiło się życie koncertowe Warszawy, ponieważ w statucie zapisano cotygodniowe koncerty symfoniczne (ewentualnie w okresie letnim - co dwa tygodnie); później miały się odbywać dyskusje o tych koncertach i pogadanki po polsku, niemiecku i francusku, włączono w to także działalność pedagogiczną (między innymi z udziałem Joachima Albertiniego). Wśród symfonii grano dzieła Beethovena, które warszawska publiczność usłyszała po raz pierwszy, Glucka, Cherubiniego, Hoffmanna. To właśnie Elsner i Hoffmann występowali w czasie tych koncertów w roli dyrygentów. Działająca przy Resursie biblioteka książek i czasopism prenumerowała m.in. lipską „Allgemeine Musikalische Zeitung”, do której z kolei Elsner wysyłał teksty o życiu muzycznym Warszawy, o czym była już mowa ${ }^{92}$.

Zdaniem Aliny Nowak-Romanowicz Elsner był pierwszym poważnym krytykiem muzycznym działającym w Warszawie. Do roku 1800 dość rzadko jeszcze zapowiadano w prasie koncerty w dużych miastach (np. w „Wiadomościach

${ }^{91}$ L. Schiwietz, Josef Elsner als Korrespondent der „Allgemeinen Musikalischen Zeitung”, [w:] Józef Elsner (1769-1854). Życie - działalność - epoka..., s. 215-221.

${ }^{92}$ Nowak-Romanowicz, Klasycyzm..., s. 49. 
Warszawskich” lub „Gazecie Warszawskiej”), czasami pojawiały się anonse w formie afisza. Dopiero na początku XIX wieku tego typu zapowiedzi stały się powszechną praktyką ${ }^{93}$. Podobnie działo się ze sprawozdaniami i recenzjami. Początkowo ukazywały się te dotyczące dzieł wokalno-instrumentalnych, dopiero później pojawiły się relacje z koncertów instrumentalnych. Krótkie notki o przedstawieniach ukazywały się już w latach siedemdziesiątych XVIII wieku. Recenzje koncertów można odnotować dopiero w wieku XIX. Dla omawianej tematyki istotny jest artykuł Elsnera z 1809 roku $O$ wirtuozach, którzy w tym czasie popisywali się z talentami swymi w Warszawie, gdyż to w nim wyłożył Elsner swoje poglądy na muzykę instrumentalną ${ }^{94}$.

Organizując i recenzując koncerty, Elsner miał wprawdzie stały kontakt z ówczesną symfoniką, to jednak od przyjazdu do Warszawy gatunek ten był dla niego coraz mniej inspirujący w sensie kompozytorskim. Im bardziej porywała go idea stworzenia narodowej muzyki polskiej, tym bliżej mu było do muzyki scenicznej, a tym dalej do symfonii, która w jego wyobrażeniach nie była w stanie pomóc w spełnieniu tak poważnej misji, jakiej się podjął. Komponował natomiast liczne dzieła sceniczne, wpisując się w nurt narodowy poprzez sięganie do tematyki historycznej i ludowej. W założonej przez Bogusławskiego Szkole Dramatycznej przy Teatrze Narodowym to właśnie on stworzył koncepcję programową. Później sam został rektorem Szkoły Głównej Muzyki ${ }^{95}$.

${ }^{93}$ Ibid., s. 47.

${ }^{94}$ Alina Nowak-Romanowicz twierdzi, że pierwsza relacja z publicznego koncertu (,Gazeta Warszawska", 10 lutego 1801, nr 12) odnosiła się do Stworzenia świata Haydna, wykonanego w dniu 6 lutego 1801 roku, a więc już w XIX wieku. Pierwszym artykułem Elsnera, w którym relacjonuje on życie muzyczne Warszawy, miałby być tekst Nachrichten aus Südpreussen, wydrukowany w „Allgemeine Musikalische Zeitung” 1805 nr 14 z dnia 2 stycznia, s. 224-227. Eadem, Klasycyzm..., s. 50 .

95 Sława Józefa Elsnera jako pedagoga jest w pełni uzasadniona, przez kilka dekad bowiem uczył on muzyki - był nauczycielem śpiewu i gry, wykładał teorię i kompozycję. Jego działalność pedagogiczna wiąże się kolejno z następującymi placówkami: wspomnianą Szkołą Dramatyczną Bogusławskiego, Szkołą Elementarną Muzyki i Sztuki Dramatycznej, Instytutem Muzyki i Deklamacji oraz Szkołą Główną Muzyki. Jego zasługi są tym większe, iż był on bardzo zaangażowany w organizację nowoczesnego szkolnictwa muzycznego na terenie Warszawy. Wystawiając świadectwo Fryderykowi Chopinowi, pisząc słowa: „szczególna zdatność, geniusz muzyczny”, Józef Elsner sam sobie wystawił najlepsze świadectwo, wykazując się tak doskonałym osądem młodziutkiego artysty. W artykule Chopin und Elsner an der Hauptschule für Musik der Königlichen Universität zu Warschau (1826-1829) Maciej Gołąb przeprowadził analizę związków Chopina i Elsnera w czasie studiów Fryderyka w Szkole Głównej Muzyki. Autor ukazał, jaki wpływ miały lata nauki pod okiem Elsnera na postawę twórczą oraz warsztat Chopina. Zob. M. Gołąb, Chopin und Elsner an der Hauptschule für Musik der Königlichen Universität zu Warschau (1826-1829), [w:] Józef Elsner (1769-1854). Życie-działalność - epoka..., s. 61-78. 
Można powiedzieć, że Elsner był człowiekiem-instytucją. Zaangażowany całym sercem w kształcenie młodych artystów, w popularyzację muzyki, w krzewienie polskości w dobie zaborów, należał do najbardziej cenionych postaci życia muzycznego Warszawy ${ }^{96}$. W latach 1802-1806 prowadził swoją sztycharnię nut. Od 1805 roku był członkiem Warszawskiego Towarzystwa Przyjaciół Nauk, w latach 1805-1806 działał w Resursie Muzycznej, od 1814 do 1825 roku zaś w Towarzystwie Muzyki Religijnej i Narodowej, sam będąc jego współzałożycielem. Był bardzo zaangażowany w działalność o charakterze narodowym. Od 1803 roku datuje się inicjatywa wydawnicza Elsnera, który postanowił wydawać miesięcznik nutowy na zasadzie subskrypcji Wybór pięknych dzieł muzycznych i pieśni polskich ${ }^{97}$.

Otrzymywał honorowe członkostwa licznych towarzystw muzycznych, utrzymywał kontakty zagraniczne. Elsner był członkiem masonerii, od 1814 roku piastując funkcję namiestnika katedry w loży Świątyni Stałości, a od 1821 roku stając się mistrzem tejże katedry. 27 września 1829 roku o. Jan Gółkowski, wizytator, podpisał decyzję o przyjęciu Józefa Elsnera w poczet konfratrów zakonu paulinów. Wraz z nim do grona tego została przyjęta jego rodzina: Karolina (żona), Emilia (córka), Karol Englert i Józef Englert (wnukowie). Elsner był także kawalerem Orderu Świętego Stanisława i członkiem Arcybractwa Literackiego przy archikatedrze św. Jana Chrzciciela w Warszawie ${ }^{98}$.

${ }^{96}$ Do entuzjastów twórczości Elsnera nie należał Hoesick, ale i on twierdził, iż: „Zmarły w dniu 18 kwietnia 1854 roku (w mająteczku swym Elsnerówce pod Warszawą) przeżył Elsner wśród nas pół wieku z kilkoletnim okładem, a jeśli w ciągu tego czasu zasłużył sobie na chlubny tytuł «twórcy muzyki polskiej», to przydomek ten wcale nie grzeszy przesadą. Wprawdzie już w wieku XVI mieliśmy Gomółkę i Szamotulskiego, (o których piękne rozprawy zawdzięczamy p. Aleksandrowi Polińskiemu), ale jak rozwój muzyki powszechnej nowożytnej datuje się od Beethovena, choć przed nim żyli i tworzyli arcydzieła tacy mistrze tonów, jak: Palestrina, Bach, Haendel, Gluck, Haydn, Mozart i wielu innych, podobnie i w dziejach naszej muzyki narodowej prawdziwa nowa epoka rozpoczyna się dopiero z przybyciem Elsnera w roku 1799 do Warszawy; wszystko, co na cześć Euterpy działo się przed nim, to były mniej lub więcej szczęśliwe prolegomena do tej prawdziwej muzyki narodowej polskiej, której najznakomitszymi przedstawicielami stali się dotychczas Chopin i Moniuszko, a którą obecnie reprezentują godnie: Żeleński, Noskowski, Münchheimer, Gall, Stojowski, Melcer i najsławniejszy z nich, «król fortepianu», Paderewski. Wszyscy oni, ilu ich wydał wiek XIX, biorą początek swój - niby rzeki z jednego źródła - od Elsnera; on jest ojcem duchowym całego pokolenia muzyków polskich, pokolenia, które muzykę naszą po raz pierwszy wprowadziło do świątyni muzyki powszechnej, europejskiej, i wyjednało tam miejsce dla niej zaszczytne, wcale nie jedno z ostatnich". F. Hoesick, Z papierów po Elsnerze (1769-1854), Warszawa 1901, s. 5.

${ }^{97}$ Zduniak, Józef Elsner ..., s. 19.

${ }^{98}$ L. T. Pietras, Józef Elsner i jego kontakty z Jasna Góra w Częstochowie, [w:] Józef Elsner (1769-1854). Życie - działalność - epoka..., s. 150 n. 
Szczególnie warto podkreślić przenikliwość i dalekowzroczność Elsnera, który zbierał wiadomości na temat muzyki polskiej i gromadził pieśni polskie, wyrażając ubolewanie, że nikt się tym nie zajmuje:

„Nie mam za złe Forklowi, badaczowi naukowemu, że w swojej powszechnej historii muzyki ani słówka nie mówi o muzyce narodowej u Słowian, o chrześcijańskiej kościelnej u Polaków i Czechów ani o muzycznych ich towarzystwach, skoro o tym zamilczają poprzednicy jego, uczeni muzycy miejscowi" $"$.

W walkę o polskość Elsner był zaangażowany całym sercem, uznając pierwiastek narodowy za podstawowy atrybut sztuki. Równolegle prowadził on ożywioną działalnością na rzecz życia muzycznego oraz promował polskość poprzez celowe wplatanie elementów muzyki ludowej do swoich utworów ${ }^{100}$. Alina Nowak-Romanowicz oraz Małgorzata Kowalska podkreślają aktywność Elsnera na gruncie gromadzenia i badania polskiej muzyki ludowej oraz specyfiki ludowego muzykowania. Bogusław Schaeffer zauważa, że to właśnie ze szkoły Elsnera wyszedł Oskar Kolberg ${ }^{101}$. Jeszcze raz warto przypomnieć, iż Elsner świadomie wplatał elementy muzyki ludowej także do swoich utworów instrumentalnych, w tym symfonii, pielęgnując $\mathrm{w}$ ten sposób polskość i przygotowując grunt dla swego genialnego ucznia ${ }^{102}$.

O ile problem pochodzenia Elsnera budził wiele wątpliwości i kontrowersji, o tyle jego wkład w polską kulturę jest oczywisty. Z punktu widzenia rodzimej muzyki symfonicznej podkreślenia wymaga jeszcze jeden niezwykle istotny moment. Właśnie w tej dziedzinie okazał się Elsner najbardziej dalekowzrocznym i przewidującym autorem. Z dzisiejszej perspektywy można już z całą pewnością powiedzieć, że to jego wskazówki i przemyślenia wyznaczyły właściwy kierunek przyszłych badań muzykologicznych. Polskie piśmiennictwo muzyczne zatoczy-

\footnotetext{
${ }^{99}$ Cyt. [za:] Zduniak, Józef Elsner ..., s. 24.

${ }^{100}$ Por. B. Mika, Polska identyfikacja w muzyce Józefa Elsnera, [w:] Józef Elsner (1769-1854). Życie-działalność - epoka..., s. 335-345.

${ }^{101}$ B. Schaeffer, Dzieje kultury muzycznej. Podręcznik dla klas I-III szkót średnich, Warszawa 1987, s. 128.

${ }^{102}$ Elsner stosował w swych utworach cytaty z polskiej muzyki ludowej, ewentualnie przetwarzał ją w sposób artystyczny, zachowując tylko ogólny charakter muzyki narodowej. Pisał też tzw. msze ludowe, wykorzystujące polskie teksty. Były one przeznaczone dla wiernych, którzy mogli w ten sposób współuczestniczyć w śpiewach. Nawet w msze łacińskie wplatał Elsner melodie polskich pieśni kościelnych, aby nadać tym kompozycjom szczególny charakter. Na przełomie XVIII i XIX wieku był on bodaj najpłodniejszym kompozytorem na ziemiach polskich w zakresie tworzenia dzieł religijnych.
} 
ło zresztą w tej materii swoiste koło, utrzymując przez cały XIX wiek pogląd, jakoby tego rodzaju muzyka polska w ogóle nie istniała, a obecnie dochodząc do stwierdzenia, że w świetle dostępnych dziś faktów to Elsner był najbliższy prawdzie, wskazując najlepszy kierunek kwerend - archiwa kościelne, przyklasztorne, kolegiackie, gdzie rzeczywiście znajdują się największe skarby rodzimej symfoniki. To on ubolewał nad utratą najbardziej bezcennych z punktu widzenia historii muzyki polskiej muzykaliów, zawierających utwory kompozytorów działających na polskich terenach (m.in. Marcina Józefa Żebrowskiego, Jana Engla); i choć według niego manuskrypty i druki z obcymi kompozycjami być może miały z materialnego, wymiernego punktu widzenia większą wartość, to polskie kompozycje były bezcenne, gdyż nie można ich odnaleźć w obcych archiwach i bibliotekach ${ }^{103}$. Niestety, w miarę upływu XIX wieku zupełnie zignorowano

103 „Bądź co bądź, żałować zawsze należy, że przed pierwszym podziałem kraju przynajmniej, choć już dawno były przeszły czasy Zygmuntowskie, nikt nie zajął się opisaniem stanowiska muzyki w Polsce, a mianowicie położenia kapeli przy katedralnych kościołach i innych fundacjach. [...] Istniało też w kraju wiele zakładów funduszowych dla muzyki kościelnej, najwięcej śpiewnej, w celu upiększenia służby Bożej, lecz te po roku 1793 w części zostały zniweczone; zakłady funduszowe utraciły dochody i wiele chórów śpiewnych po kościołach nie mogło się dalej utrzymać. Pozostała tylko najznakomitsza muzyka kościelna przy Zamkowym kościele w Krakowie, posiadająca w swojem archiwum znaczną ilość dzieł muzycznych z przeszłości i teraźniejszości, które na własne oczy w 1793 roku widziałem. Trudno jest oznaczyć, co się tam z tego dziś jeszcze znajduje, bo kto wie nawet, czy i to istnieje, o czem ksiądz prałat hrabia Sierakowski w swem dziele o muzyce w Krakowie napisanem, mianowicie w katalogu przy niem załączonym, wspomina, jako o znajdującym się jeszcze przy katedrze. Jako powód powątpiewania przytaczam, że przy braku funduszów i podobnych okolicznościach nadzór nad archiwum zapewne nie był najsumienniejszym, a przytem, wiele zapewne chcąc nie chcąc zaginąć musiało, albowiem po cóż było zadawać sobie pracę nad przepisywaniem lub ponosić koszta przepisywania, kiedy sam oryginał (który już i tak nie mógł i nie miał być wykonany) łatwo było otrzymać; o czem, niestety, osobiście się przekonałem. I tak w Warszawie, gdzie królewska kapela, (mianowicie w święta, gdy król bywał na nabożeństwie, wzmacniała kapelę przy Farze będąca[ą], a złożoną prócz kapelmistrza i organisty z małej liczby członków) miała znakomity nutozbiór, wszystko to po opuszczeniu przez króla Warszawy, na poddaszu Zamkowem złożono. Ilość zaś tych dzieł musiała być niemałą, sądząc z tego, co mi jeszcze za pruskich czasów w roku 1805 rządca Zamku, Mejnert powiadał: «Dziwiłbyś się p. Elsner, gdybyś widział owe mnóstwo nut naszych!» Dziś ani śladu ich nie ma. Zapewne czeladnicy mularscy i pomocnicy przy poprawie Zamku i dachów, następnie i chłopcy kominiarscy, powynosili je mało po mału do sklepików i szynków; tem bardziej, że owe archiwum muzyczne leżało tam bez dozoru. Toż samo stało się przed kilku laty w tutejszym katedralnym kościele. Zwykle wykonywano w nim muzyki kościelne w obu chórach, położonych w presbiterjum przed wielkim ołtarzem. W lewym mieścił się organista, śpiewacy, kotły i trąby, w prawym zaś pomieszczane bywały pozostałe instrumenta. Wybrano razu jednego do naprawy lewego chóru wielki post, podczas którego organy i instrumentalna muzyka skazanemi są na milczenie; a po ukończeniu lewego chóru, wziąwszy się do chóru prawego, cała orkiestra przez czas niejaki mieścić się musiała w le- 
zalecenia Elsnera, koncentrując się niemalże tylko i wyłącznie na operze z czasów stanisławowskich. Zaistniała niezwykła sytuacja, w której już po upływie kilkudziesięciu lat Polacy uznali, że w minionych wiekach, a więc m.in. w wieku XVIII rodzima muzyka w ogóle nie istniała! ${ }^{104}$.

Jak na kompozytora przynależnego do kultury polskiej Józef Elsner stworzył stosunkowo wiele symfonii. Rodzimi twórcy XVIII oraz przełomu XVIII i XIX wieku nie wykazywali bowiem tak dużego zainteresowania tym gatunkiem jak kompozytorzy wielu innych krajów europejskich. Mimo ogromnej popularności symfonii, szczególnie w kręgach kościelnych, zdecydowana większość repertuaru pochodziła z zagranicy. Elsner należał do wąskiego grona polskich twórców, którzy już posługiwali się środkami ukształtowanymi przez Haydna i Mozarta, komponując utwory odpowiadające stylistycznie przede wszystkim wzorcom wiedeńskim. Zamykają oni tok rozwojowy rodzimej symfonii z XVIII wieku.

$\mathrm{Na}$ tle ówczesnej twórczości symfonicznej powstającej na ziemiach polskich utwory Elsnera wyróżnia celowe wplatanie wątków narodowych, a nie tylko

wym przy organach. Było to już za czasów Stefaniego kapelmistrza, będącego twórcą tyle znanej opery z textem Bogusławskiego Krakowiacy i Górale. Kiedy znów w obu chórach rozpoczęto muzykę, pokazało się, iż głosy śpiewne i organowe zwykle wykonywanych Mszy, Nieszporów, Hymnów i t. p. Lassexa i innych kompozytorów, nierozważnie zostawione, podczas naprawy chóru zaginęły. Wielka a nieodżałowana szkoda zatraconych nut, złożonych na poddaszu Zamkowem, między któremi znajdowały się utwory Warszawskich artystów; na przykład Engla, kapelmistrza przy katedrze, dalej Zebra, a o ile dowiedziałem się od starych muzyków, Hanschilda, Eignerta i innych. Wprawdzie nie tyle mi chodzi o utwory z Włoch sprowadzone i bez wątpienia drogo opłacone przez poczciwych a pobożnych Polaków, ponieważ gdziekolwiek można by ich jeszcze dostać, ale bardziej o te, co były napisane przez polskich ówczesnych lub przynajmniej w ówczesnym muzycznym okresie w Polsce żyjących kompozytorów. Żałować przede wszystkiem należy, że Polska nie miała swego Foskla w osobie von Holoff Mitzlera, gdyż mu w tym względzie nie brakło na znawstwie i wiadomościach, ani na duchu przedsiębiorczym i pilności. Byłby on niezawodnie odkrył w Polsce obfite i bogate źródło starodawnych i odwiecznych melodyj słowiańskich, a co więcej greckiego jeszcze pochodzenia, których lud w chrześcijańskich kościelnych pieśniach używał, a których Foskel na próżno w Niemczech szukał”. Cyt. [za:] Hoesick, op. cit., s. 35 n.

${ }^{104}$ Dowodzą tego opisane wcześniej apele Józefa Sikorskiego z 1849 roku i redakcji „Echa muzycznego" z 1879 roku, na które Polacy odpowiedzieli jednoznacznie, że wcześniej nie było muzyki polskiej. Tematyka ta jest szeroko omówiona w artykule: B. Stróżyńska, W mrokach niepamięci czyli jak zapomniano o XVIII-wiecznej polskiej muzyce instrumentalnej. Przegląd polskiego piśmiennictwa muzycznego do roku 1950, [w:] Mozart i wspótcześni. Muzyka w Europie Środkowej w XVIII wieku, red. R. D. Golianek, B. Stróżyńska, Łódź 2007, s. 191-203. 
spontaniczne posługiwanie się elementami muzyki ludowej, które w większości wypadków rodzimych twórców z XVIII wieku nie było świadomym aktem woli, ale wynikało z - jak to kiedyś chętnie określano - plebejskiego pochodzenia i wzorców wyniesionych z dzieciństwa. Elsner nie był jedynym muzykiem wplatającym wątki narodowe do symfonii, ale było to wówczas jeszcze zjawisko stosunkowo rzadkie. Należy więc uznać, że o ile od strony muzycznej stosowanie elementów polskiej muzyki ludowej wpisywało się w powszechną praktykę kompozytorską, nie stanowiąc wyznacznika postępowości, a raczej swoistą normę, o tyle od strony ideowej pojawienie się symfonii stworzonych w nurcie narodowym stanowiło znaczący, ważki moment.

Trudno ocenić znaczenie Elsnera w historii rodzimej symfonii, większość bowiem jego dzieł tego gatunku zaginęła, były to zarazem utwory w dużej mierze młodzieńcze. Na pewno na tle całego dorobku kompozytorskiego Elsnera ich znaczenie jest niewielkie. Trudno też w nich znaleźć jakieś cechy szczególne, nowe środki wyrazu czy przejawy oryginalnego warsztatu twórczego, które by wyznaczały nowe, XIX-wieczne tory rozwoju rodzimej symfoniki. To raczej zamknięcie minionej epoki. Bardziej znaczące wydają się natomiast wielorakie związki z kompozytora muzyką symfoniczną w kolejnych ośrodkach, w których działał. Elsner krzewił ten gatunek, wprowadzał symfonie do programów licznych koncertów, tworzył podwaliny nowoczesnej sztuki recenzowania tego typu dzieł. Ożywiona działalność na tym polu to jeszcze jeden dowód ogromnego zaangażowania i nieocenionych zasług Józefa Elsnera dla kultury narodu, który już nie miał swojego państwa, ale za to zajął tak ważne miejsce w jego sercu.

\section{SUMMARY}

The views of Józef Elsner on instrumental music clearly indicate his attachment to esthetic assumptions formed in the 18th century. The analysis of his writings shows numerous analogies to statements of prominent 18th century European music theorists (e.g. Heinrich Christoph Koch, Johann Nikolaus Forkel, Johann Philipp Kirnberger). Characteristic of Elsner's creative path is the fact that in the beginning he valued vocal music more but during this period he very willingly composed instrumental pieces; later when he concluded that also musical pieces without verbal contents could also influence feelings, he devoted himself to vocal-instrumental music.

His lack of interest in the historical symphony trend i.e. connected with events important to Poles seems mysterious. His engagement in cultivating Polishness and upholding the spirit in an enslaved nation seemed to be a good pretext to compose such pieces of music. However, it seems that using Polish folklore was, according to Elsner, enough to show the national character of his symphonies. Although almost all his symphonic works 
have been lost, it can be concluded (on the basis of the preserved Symphony in C major Op. 11, which has been comprehensively analyzed in this study) that Elsner's stylistic symphonies fit, first of all, into the patterns of Viennese Classicism.

Elsner undertook the initiatives which were aimed at the development of modern forms of musical life on Polish soil. His merits in promoting symphonic music seem very important. In 1796 Elsner founded the Music Academy in Lvov. Within concert activities of this society, he presented here many symphonies, inter alia the symphonies of Joseph Haydn and Wolfgang Amadeus Mozart. There is no doubt that the symphonic pieces composed by Elsner during this period were meant for the Lvov Academy. From 1799 on, Elsner was giving concerts in Warsaw. Although, as an organizer of the concerts and a reviewer, Elsner had a constant contact with the then symphonic music, it seems that since his arrival in Warsaw he was less and less interested in composing symphonies. The more he was interested in the idea of composing Polish national music, the closer he was to the creation of theatre music rather than symphonic music, which, according to him was of no help in conducting such a serious mission. At the same time, as the author of numerous writings, it was symphonic music where he showed his wisdom and far-sightedness. His advice and reflections showed the proper direction of studies, concentrating on church, monastery, and collegiate archives. In the 20th century it appeared that they hid the greatest treasures of national symphonic music. It should be stressed that Elsner deplored very much the loss of priceless manuscripts and old-prints - from the point of view of the history of Polish music - with the works of Polish composers, including symphonies; he emphasized that these pieces were much more important for national culture than the ones composed by foreign composers. Unfortunately, during the 19th century his suggestions were completely ignored and after a few dozen years the Poles concluded that in the 18th century, symphonies were not composed in the Commonwealth of Poland. 